Portland State University

PDXScholar

$5-1972$

\title{
A Study of the Legal Aid Family Law Center and its Clients, by Cynthia Ann Thomas [and] Susan Marie
}

\section{Vail}

Cynthia Ann Thomas

Portland State University

Susan Marie Vail

Portland State University

Follow this and additional works at: https://pdxscholar.library.pdx.edu/open_access_etds

Part of the Family Law Commons, and the Social Work Commons

Let us know how access to this document benefits you.

\section{Recommended Citation}

Thomas, Cynthia Ann and Vail, Susan Marie, "A Study of the Legal Aid Family Law Center and its Clients, by Cynthia Ann Thomas [and] Susan Marie Vail" (1972). Dissertations and Theses. Paper 1582.

https://doi.org/10.15760/etd.1581

This Thesis is brought to you for free and open access. It has been accepted for inclusion in Dissertations and Theses by an authorized administrator of PDXScholar. Please contact us if we can make this document more accessible: pdxscholar@pdx.edu. 
PRACRICUM REPORT OF Cynthia Ann Thomes and Suran Maric Vail Por the Master in Social Work presented Mny 26, 1.972.

Witle: A Study of the Legal Aid Family Law Center and its Clients.

APPROVED BI MENBERS OF THE PRACTICUM REPORT COMMITTEE:

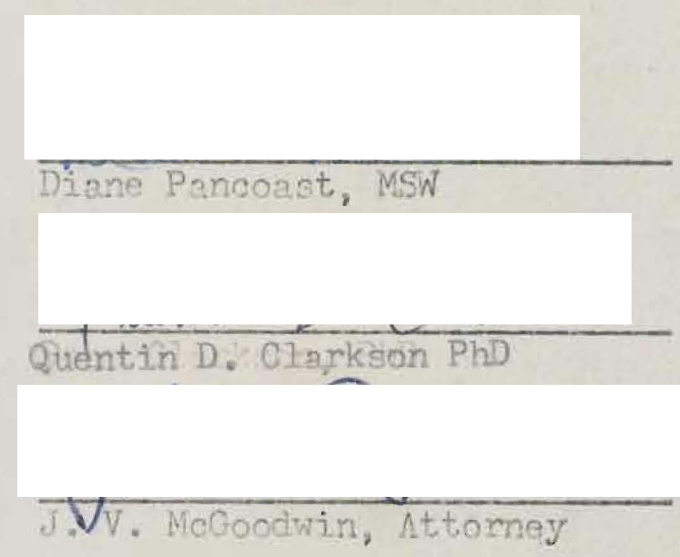


A STUDY OF THE IECAL AID FAMTLY LAW CENTER

AND ITS CLIENTS

by

CINTHIA ANN THOMAS

SUSAN MARTE VAIL

A practicum report submitted in partial fulfillment of the requirements for the degree of

MASTER in SOCIAL WORK

Portland State University.

1972 


\section{ACKNOWLEDGMENTS}

We would like to horeby gratefully acknowledge and give many thanks to the persons who were of such invaluable assistance to us:

To the Iegal Aid Client who cooperated by answering our questions we are more than grateful;

To the Family Law Conter of Legal Aid, especially J. V. McGoodwin and his secrotaries, without whose help this study would have been impossible.

To Dr. Clarkson for the many helpful suggestions, adviee, and numerous stories and anecdotes;

To Diane Pancoast for her patience;

And last, but most definitely not least, to Rance and Spencer, a special thanks for their tolerance. 
TABTE OF CONTENTS

PAGE

ACKNONLEDGMENTS ...................

IIST OF TABIES ...................

CHAPTER

I INTRODUCTION ......................... 1

Iegal Aid ................. 1

Family Law Center ........... 2

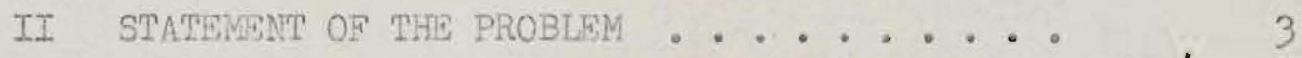

Objectives ...................... 3

III RESEARCH DESTGN ................... 4

Time Schedule ................... 6

IV DISCUSSTON OF DATA .............. ?

Retum Rate .............. ?

Sex 8

Age ................... 8

Race...................... 9

Employment ................. 9

Welfare ................ 9

Income .............. 9

Education ............ 10 
Iiving Situation - Physical .....

Living Situation - Social ......

Part of Town .............

Ages of Children ...........

Number of Children .........

Iiving Situation of Children ......

Children Suffering ..........

Length of Marriage ..........

Number of Marriages ..........

Separation .............

Soparated - Lencth of Timo .......

Separated - Who Left. . . . . . . .

Separated - Nunber of Times ......

Help With Femily Problems

Reasons For Divorce

Spouse Providing For Children

Child Support

Marriage Counseling .........

Logal Aid - Referral .........

Legal Aid - Previous Contect ......

Legal Aid - Reason . . . . . . . .

Legal Aid - Transportation . ......

Acencies Seen in the Past Year .....

VI RECOMMEIIDATIONS .............. 
CHAPTER

APPENDTX ................... 


\section{LIST OF TABLES}

TABLE

I Questionnaires .............

II $\operatorname{Sex} \ldots \ldots \ldots \ldots$

III Age ...................

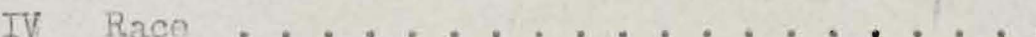

V Employed ....................... 28

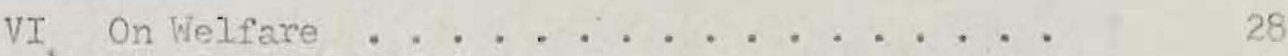

VII Income ................. 29

VII Education (part 1) .......... 29

IX Edrication (part 2) ............ 30

y Where Living ........................ 30

XI Who Iiving With Now ............ 31

XII What Part of Iown Do You Live In ...... 3 I

XIII Ages of Children (part l) ....... 32

XIV Number of Children In Frmily ....... 32

XV Where Are Children Iiving Now ......... 33

XVI Have Children Suffered From This Maxriagc . .

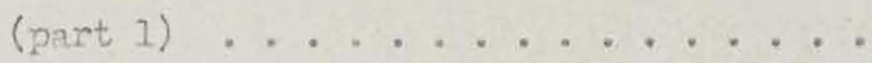

XVII If Yes: How (part 2) ......... 34

XVITT How Long Have You Been Married ........ 34

XIX Number of Times Herried......... 35

XX. Are You Separated Now (part 1) ...... 35 
TABLE

XXI How Long This Time (part 2) ........ 36

XXII Who Left This Time (part 3) ....... 36

XXIII How Many Times Separated (part 4) ...... 37

XXIV What Have You Thought About to Help With Your

Family Problems............... 3 ?

XXV If You Are Considering a Divorce: Why .... 38

XXVI Is Spouse Providing for Children Now (part.1). 38

XXVII If Yes: How (part 2) .............. 39

XXVIII Do You Want Child Support (part 1) ...... 39

XXIX, If Yes: Will You Demand Support (part 2) ... 39

XXX If No: Is It Because He Won't Pay Anyway

(part 3) ................... 40

XXXI Have You Ever Seen a Marriage Counselor .... 40

XXXTT How Did You Know About Legal Aid ........ 40

XXXIII Have You Ever Been to Legal Aid Before (part

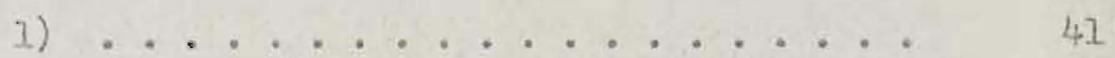

XXXIV If Yes: Why (part 2) ........... 4 I

XXXV Did You Come to Legal Aid Because of Lack of

Money for a Private Attorney ...... 42

XXXVI How Did You Get to Legal Aid Today . . . . . 42

XXXVII Which Agencies Have You Seen in the Past Year . 43

XXXVIII Conclusions .............. 44 
IIST OF GRAPHS

GRAPH

PAGE

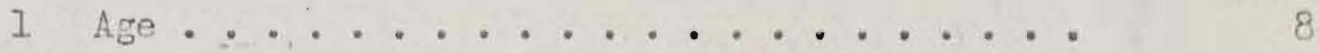

2 Income ......................... 10

3 Ages of Children ....................... 12

4 Number of Children in Family ......... 13

5 How Long Have You Been Married........ 25

6 How Long Separated This Time........ 17

7 How Many Times Separated ............. 18 


\section{INTRODUCTION}

The family is the basic unit in our society. When there is a breakdown in this unit, specifically in the marital relationship, the effect upon the husband, wife, and children can be devastating in terms of poverty, abuse, and cost to society. The frequent inability of the poor to obtain counseling and legal assistance in resolving family relationships perpetuates the social and psychological results of a poor marriage.

\section{Legal Aid}

The function of Legal Aid Services in Multnomah County has been to render legal assistance to persons unable to afford the services of a private attorney. In 1970, approximately $42 \%$ of the 7,797 people who applied for legal aid service in Multnomah County had domestic relations problems. Divorces have demanded a large percentage of the staff attorneys and secretarial time at Legal Aid; too, there was not sufficient time to adequately meet the needs of the clients. These two problems resulted in a six-month waiting period to see an attorney.

The real problem of people needing services of both legal and counseling nature led to the development and expansion into a new area of service, to enable the poor to obtain counseling and legal assistance in handing problems in family relationships. 
Family Law Center

The Family Law Center opened August 2, 1971 with the objective to expand and improve continuing legal services to its family law clients in two directions: 1) to make the legal process more efficient and less consuming of the client's time and efforts; and 2) to offer an integrated service of counseling assistance and legal assistance to the clients of the Family Law Center.

This Center was the first attempt to utilize the services of a trained social worker at the time of intake. The procedure is to offer the services of the counselor at the time of intake by asking the client if he wishes to speak with a counselor to help him with his problems. 


\section{STATEMENT OF THE PROBLEM}

This study is concerned with poor persons and their ability to receive both legal and counseling services for their family problems. Other concerns are with the questions of alternatives to divorce for the client, the effects of marital breakup on the children, and the possibility and utility for a social worker to have a role in the legal process.

\section{Objectives}

For the above reasons we chose to study the clients who came to Legal Aid Family Law Center with the purpose of examining the following four main areas of concern:

1) who the client is; where he lives;

2) why or if the client wants a divorce;

3) why the client came to Legal Aid and his contact with other agencies; and

4) whether the client has considered counseling to help with his problems.

In the areas studied, it was found that Legal Aid did not have any information gathered in a regular, consistent manner. We, therefore, desired in this study, to furnish data of real value for future use in planning for the Family Law Center. 


\section{RESEARCH DESIGN}

The data reported and analyzed in this study was gathered by means of questionnaires. The advantages of questionnaires as a method of data collection far outweigh the disadvantages, for the purposes of this study.

The method used is impersonal; the questions were presented with exactly the same wording and same order to each respondent to ensure that all respondents were replying to the same question; also, there were standardized instructions for recording responses. These elements helped to ensure some uniformity from one respondent to another. Such uniformity does not, however, eliminate the possibility of some questions having diverse meanings for some and being incomprehensible for others.

By design, questionnaires rely heavily on the respondent's self report; information obtained is limited to written responses to prearranged questions. Although we feel compelled to at least raise the issue of credibility, we have, nevertheless, selected to accept the responses given at face value, relying only on information supplied by the client.

The questionnaire was annonymous with no apparent identifying information. A statement at the top of each page indicated that the client was under no obligation to respond to any or all of the questions asked. It warrants mentioning, however, that anonymity 
and no obligation does not necessarily induce frank answers, freedom to divulge information that otherwise might place a person in an unfavorable light, or that respondents felt no pressure to cooperate.

In formulating the questions there were many presumptions made of what was or was not relevant. These presumptions were. primarily derived from the following sources: 1) a 1970 study of Legal Aid done by a Reed College student; 2) Dr. Dean Clarkson, who reviewed our original questions and offered suggestions; 3) Attorney James McGoodwin who assisted in rewording of many questions; and 4) ourselves, with backgrounds and experience in working with low-income families at Welfare and in child development.

In our attempt to present questionnaires in a context that would motivate the client to cooperate, we placed importance on: 1) length, one page; 2) ease in completion (where feasible, check marks were requested); and 3) simplified wording to avoid misinterpretation.

Another concern was with asking questions to obtain information about what the client knows, feels, wants, and intends to do. The majority of our questions limited the responses to stated alternatives. This type of question helped to insure that the responses were given in a frame of reference relevant to the purpose of the study as well as responses which were usable in analysis. This limitation, however, allowed no opportunity for other responses except when the client chose to write an additional response. 
Each questionnaire was consecutively numbered for the purpose of determining the total that were handed out, returned, and completed.

The Family Law Center secretary handed out the questionnaires to each client at the time of his initial intake interview. She also assisted those persons who requested assistance in either reading or completing the form. The sample itself is random in that we assume that the actual scheduling of intake appointments is done randomly (when the client calls to make an appointment).

\section{Time Schedule}

The period of our sample was from August 2, 1971 to October 31, 1971. This two-month sample period of a total population gives some assurance that the odds are great enough that the sample is sufficiently representative of the population to justify running the risk of taking it as representative of the total population. 


\section{DISCUSSION OF DATA}

A copy of the questionnaire is Exhlbit A in the Appendix; all tables of compiled data from each question will also be found in the Appendix.

In the following analysis and discussion of the data gathered by each question on the questionnaire, a11 information given by both female and male respondents about their spouses (Questions 1-9) was disregarded for the purposes of this report due to limited responses about the spouse which would have inconclusive results.

\section{Return Rate}

(Table I in Appendix) A total of 293 questionnaires were handed out with $243(83 \%)$ returned completed, 28 (9\%) returned blank, and $22(8 \%)$ not returned.'

The high return rate can be accounted for in several ways: 1) skillful handing and administering by the Legal Aid secretary; 2) extremely cooperative clients; and 4) clients may have felt pressured to respond even though the instructions explained that they did not have to answer.

Also, some comments need to be made about those questionnaires that were not returned and those returned blank. Several assumptions about this are: 1) the obvious reason being that the client did not choose to supply the information; 2) they may not have had enough time to complete it; and 3 ) they may have been unable to read and/or write. 
Sex (Question 1)

(Table II in Appendix) The ratio of females to males is 9 to 1. This raises the question of whether this rate also correlates with clients of higher income levels who see private attorneys for domestic relations problems. This would be valuable information which we cannot supply as our focus was only on this specific data.

\section{Age (Question 2)}

(Table III in Appendix) Graph 1 shows the highest percent of females (38\%) were between the ages of $21-25$. This percent (38\%) was the same for males in the same age range.

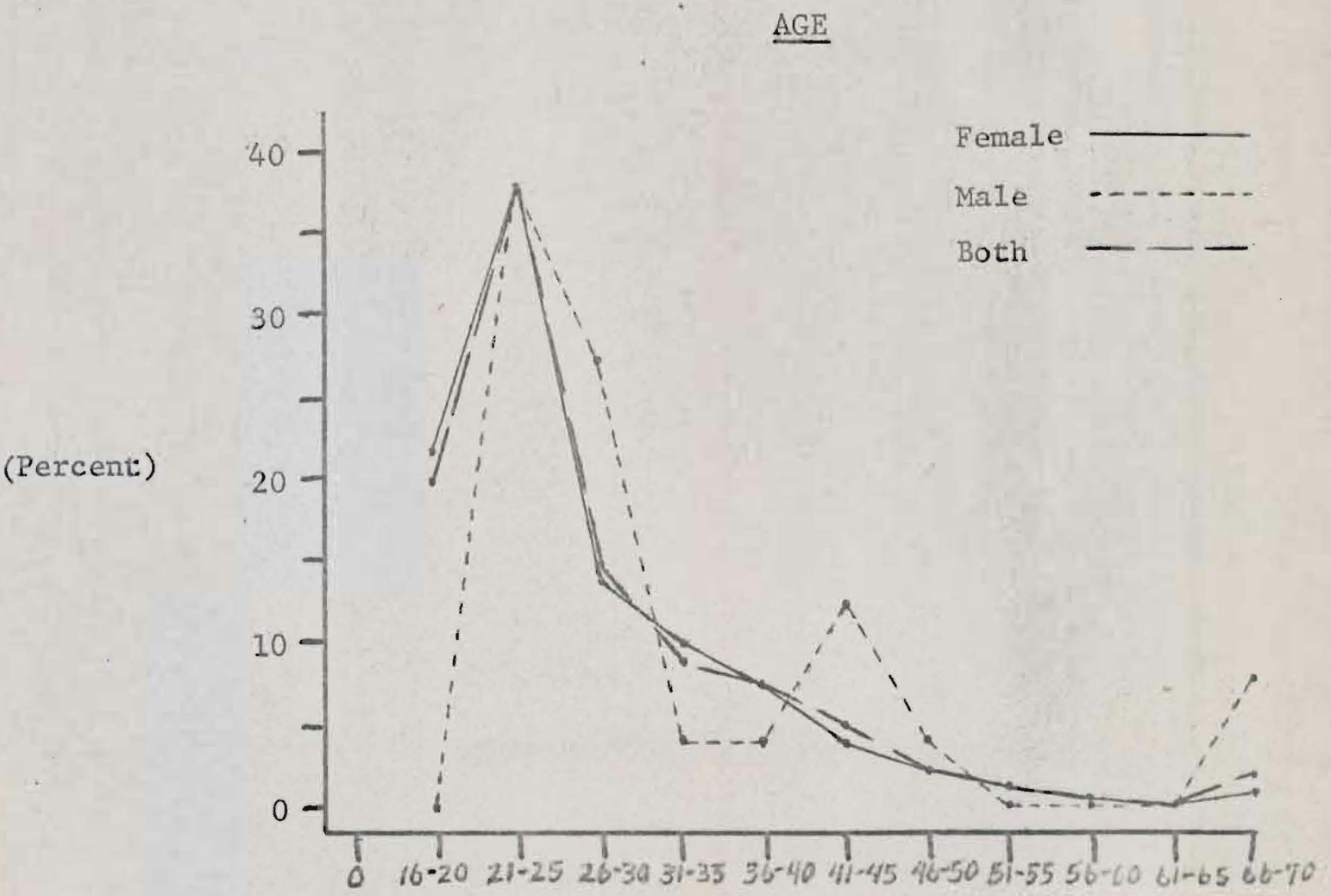


The majority of females (60\%) were younger than 26 , and the total ages of females ranged from 16 to 68 . The majority of males $(65 \%)$ were between the ages of 21 and 30 , and the age range for all males was 21 to 68 . The combined totals of both sexes show the highest percent (38\%) falling in the $21-25$ age group, with $(60 \%)$ under 26 years of age, and (75\%) 30 years or younger.

\section{Race (Question 3)}

(Table IV in Appendix) of the total number of respondents, (88\%) were white, $(8 \%)$ black, and $(3 \%)$ other non-whites. These percentages closely correspond with the racial composition of the Portland area which, in 1970, was approximately (94\%) white, (5\%) black, and (1\%) all other non-whites. This would indicate that these clients were proportionately representative of the larger population.

Employment (Question 4)

(Table V in Appendix) Three out of every four clients was unemployed, with no difference between the sexes.

\section{Welfare (Question 5)}

(Table VI in Appendix) Two out of every three females were receiving Welfare assistance; whereas, only one male out of the 23 who answered was on Welfare.

\section{Income (Question 6)}

(Table VII in Appendix) Graph 2 shows that over one-half of the females $(59 \%)$ had an income between $\$ 100$ and $\$ 300$ per month. 
One-half of the males $(50 \%)$ were in this same income range. Males and females combined, $(65 \%)$ had incomes less than $\$ 300$ per month. Six percent of the females and (15\%) of the males had no income. The incomes ranged from $\$ 0$ to $\$ 380$ for males, and from $\$ 0$ to $\$ 400$ for females, with one female having an income of $\$ 900$ per month.

\section{INCOME}

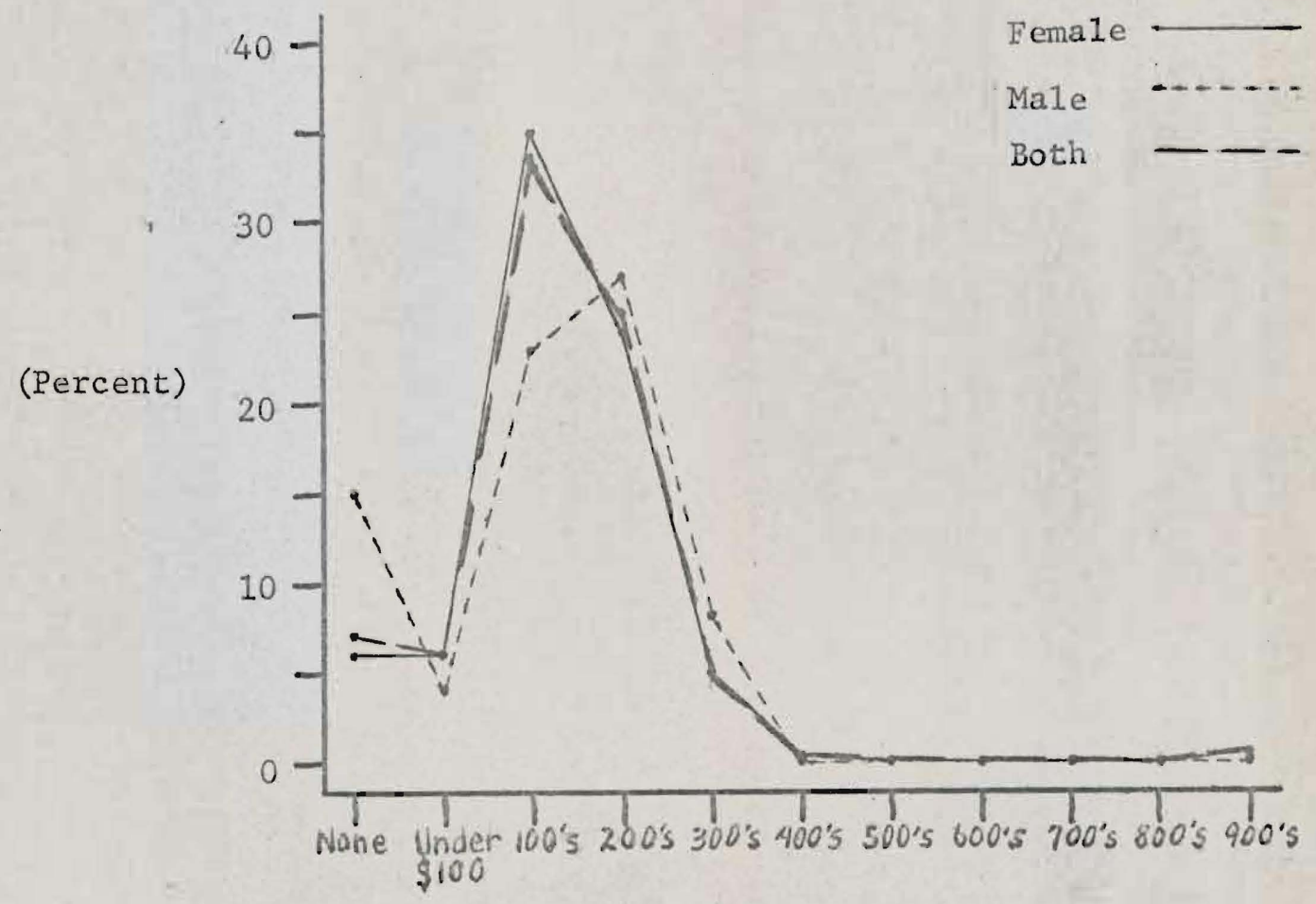

GRAPH 2

(Dollars per Month)

\section{Education (Question 7)}

(Tables VII \& IX in Appendix) The same percentage (65\%) of females and (65\%) of the males finished high school or G.E.D. high school equivalency. 
There was a very high rate of no response, (86\%) for females and (92\%) for males, for the training section of this question. This, however, does not necessarily mean that the client did not have additional training other than academic; it does indicate that this was a poorly designed question. The instructions given were "check one" and this did not allow for an additional response after answering the questions about school.

\section{Living Situation - Physical (Question 8)}

(Table $X$ in Appendix) Both males (65\%) and females (76\%) were renting either a house or an apartment; males and females combined, (75\%) were renting a house or an apartment. Only (5\%) of the females and $(8 \%)$ of the males owned their own homes.

\section{Living Situation - Socia1 (Question 9)}

(Table XI in Appendix) This was a poorly worded question. "With Children" was intended to mean that the client was living in the home of his children, but it was interpreted by some clients to mean that their children were living with them.

No conclusions can be drawn from these responses, except that only $(28 \%)$ of the females contrasted with (42\%) of the males were living with someone else; combining male and female responses, (30\%) were living with someone else.

\section{Part of Town (Question 10)}

(Table XII in Appendix) Sixty-five percent of the females and $(65 \%)$ of the males were living on the eastside of town with the majority living in Southeast Portland (females, $43 \%$ and males, 38\%). 
Ages of Children (Question 11)

(Table XIII in Appendix) Graph 3 shows that the highest percentage of the children of female clients (40\%), and of male clients (55\%) were between the ages of 1 and 5 .

\section{AGES OF CHILDREN}

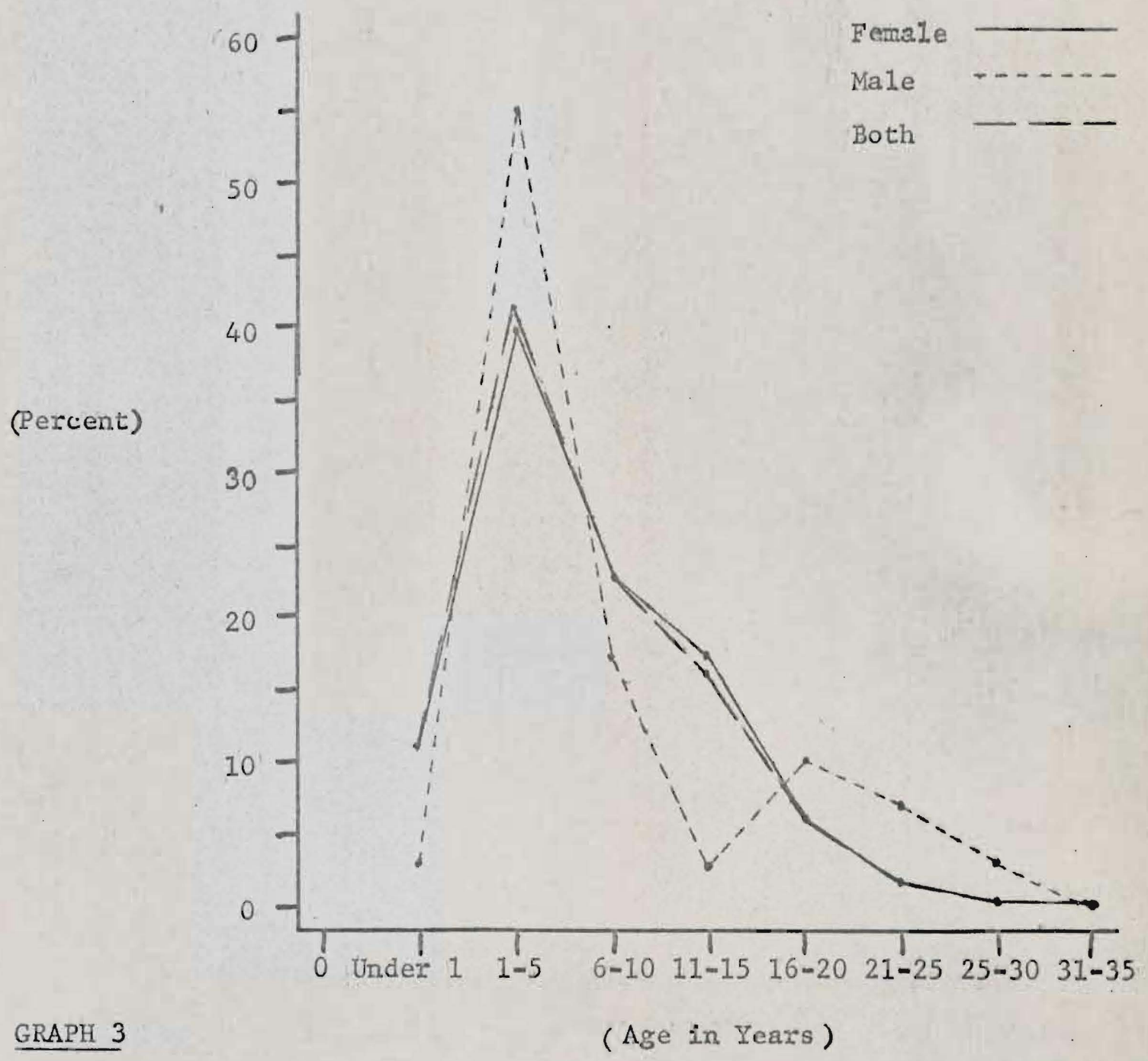


The majority of the children were between the ages of 1 and 10 , and $(75 \%)$ of the total number of children of both male and female clients were under 10 years of age. Only (11\%) were under 1 and $(24.6 \%)$ were over 10 with the oldest child of a fenale client being 34 , and 26 years for the male clients.

\section{Number of Children (Question 11)}

(Table XIV in Appendix) This information was obtained from the responses to the question about the ages of the children.

Graph 4 shows that (53\%) of the females and $(42 \%)$ of the males had 1 to 2 children; also, (72\%) of the females and (50\%) of the males had 3 children or less.

\section{NUMBER OF CHILDREN TN FAMILY}

(Percent)

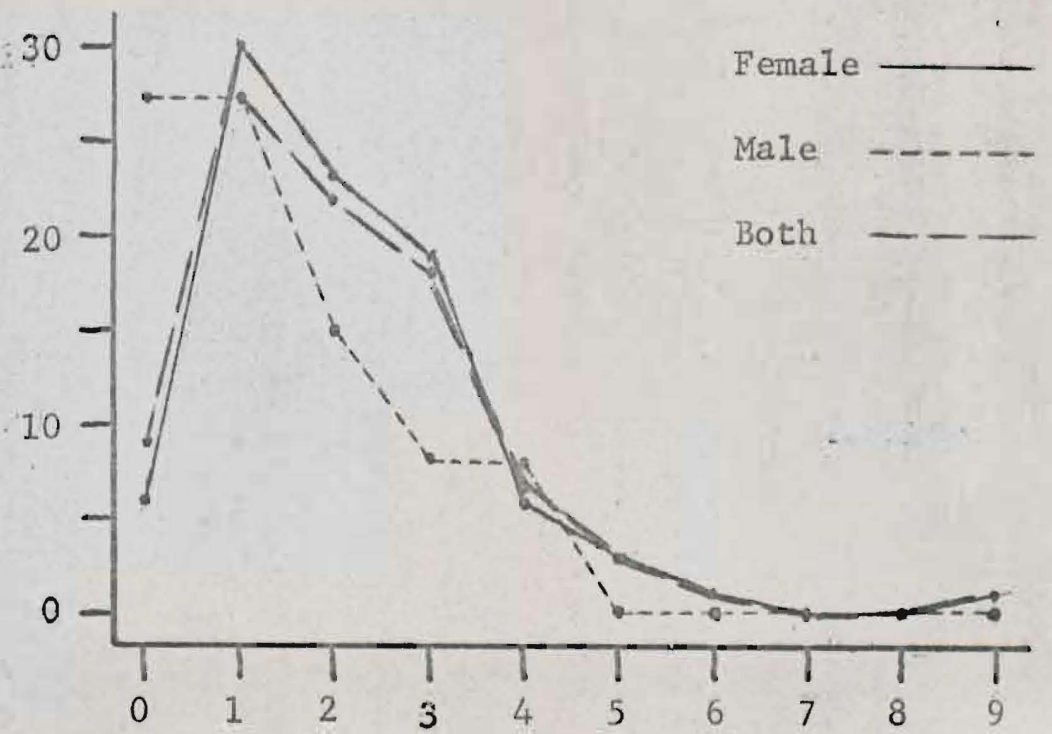

\section{GRAPH 4}


This data indicates that low-income persons have no more children than the general population; however, this is also a very young clientele and this may account for the fewer number and younger ages of the children.

\section{Living Situation of Children (Question 12)}

(Table XV in Appendix) The majority of the females (77\%) indicated that the children were living with them; $(5 \%)$ indicated that the children were living with the husband; and, (8.4\%) indicated that the children were in other living situations. There was a $(38 \%)$ rate of no response to this question by the males; but, of those responding, (38\%) said they had the children living with them, and $(29 \%)$ said the children were with the wife.

\section{Children Suffering (Question 13)}

(Tables XVI \& XVII in Appendix) The percent of clients answering "No" to this question (females, 5.\% and males, 58\%) raises the question in our minds of whether the client was willing or unable to admit or see their children as suffering from the marriage. However, our expectations of a higher "Yes" response may strongly indicate our social work bias regarding the damaging effects which a breakup in marriage and family can have upon children.

Although it is difficult to say anything significant about the "Yes" responses to this question, with only 60 of the females and 6 males responding in this way, we did find that (37\%) of the 66 responses indicated bad behavior as the manner in which the child suffered. 
Length of Marriage (Question 14)

(Table XVIII in Appendix) As shown in Graph 5, the greatest number of females $(60 \%)$ and males (62\%) were married less than five years. The range was from less than one year for both male and female to 37 years (female) and 28 years (male). Eighty-five percent of the females and ( $89 \%$ ) of the males were married less than 10 years. Only (12\%) of the females and $(8 \%)$ of the males were married more than 10 years.

\section{HOW LONG HAVE YOU BEEN MARRIED}

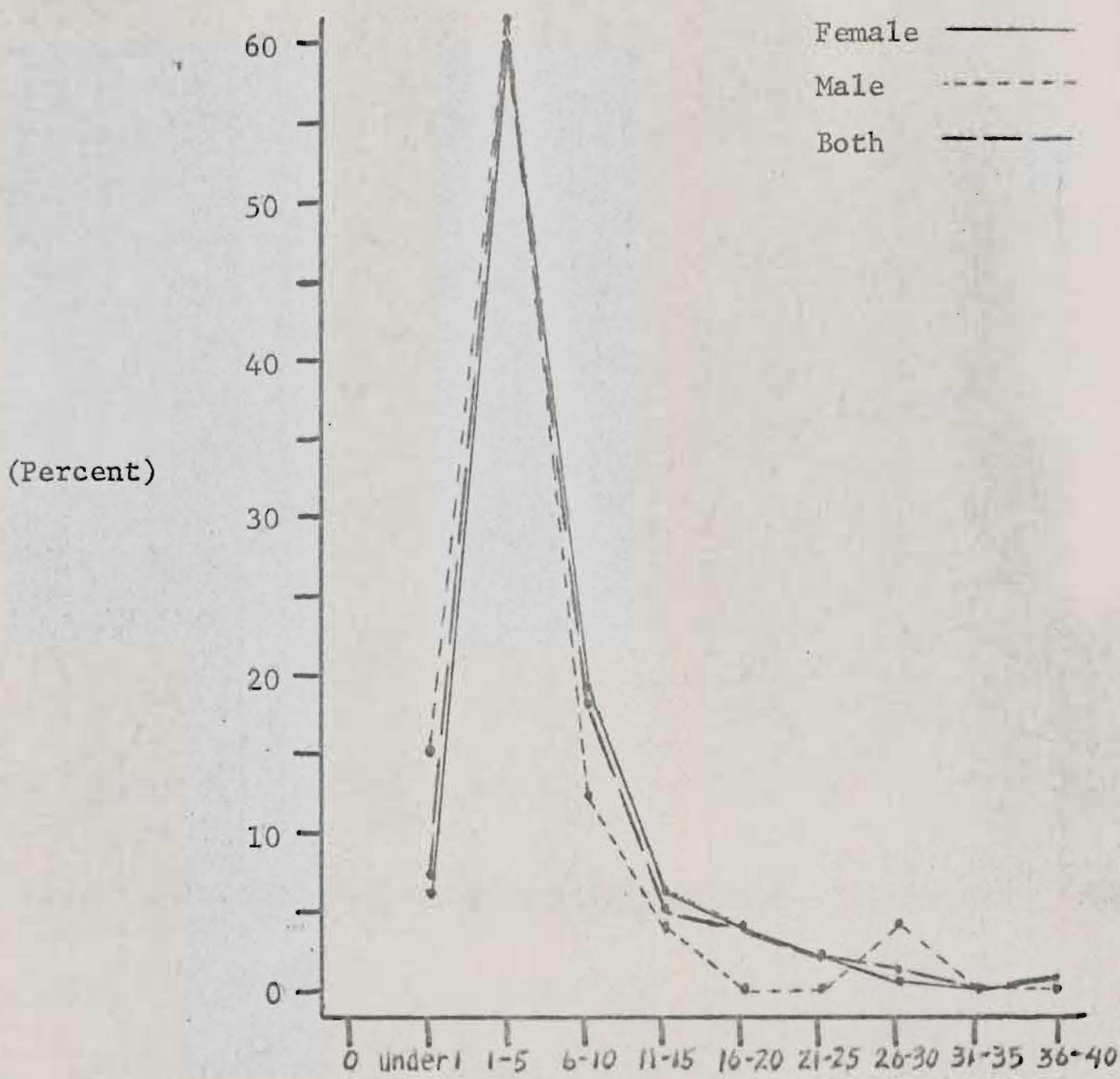


Number of Marriages (Question 15)

(Table XIX in Appendix) The majority of the females (71\%) and of males (62\%) were married only one time; combining male and female responses, (70\%) were married only one time.

\section{Separation (Question 16)}

(Table XX in Appendix) Only (5\%) of the females and (4\%) of the males were not separated at the time of intake. Ninety-four percent of the females and $(92 \%)$ of the males were presently separated; combining male and female responses, (94\%) of both were presently separated.

\section{Separated - Length of Time (Question 16)}

(Table XXI in Appendix) As shown in Graph 6, the highest percentage of the clients had been separated from 1 to 6 months (females, $51 \%$ and males, $38 \%) ;(65 \%)$ of the females and (58\%) of the males had been separated from 1 to 12 months. On $1 \mathrm{y}(8 \%)$ of the females had been.separated for less than 1 month, and 1 female had been separated for 7 years.

Separated - Who Left (Question 16)

(Table XXII in Appendix) The females responded equally for self $(43 \%)$ and spouse (41\%) leaving. Fourty-six percent of the males indicated that the spouse left, and only (27\%) indicated that they left. 
HOW LONG SEPARATED THIS TTME

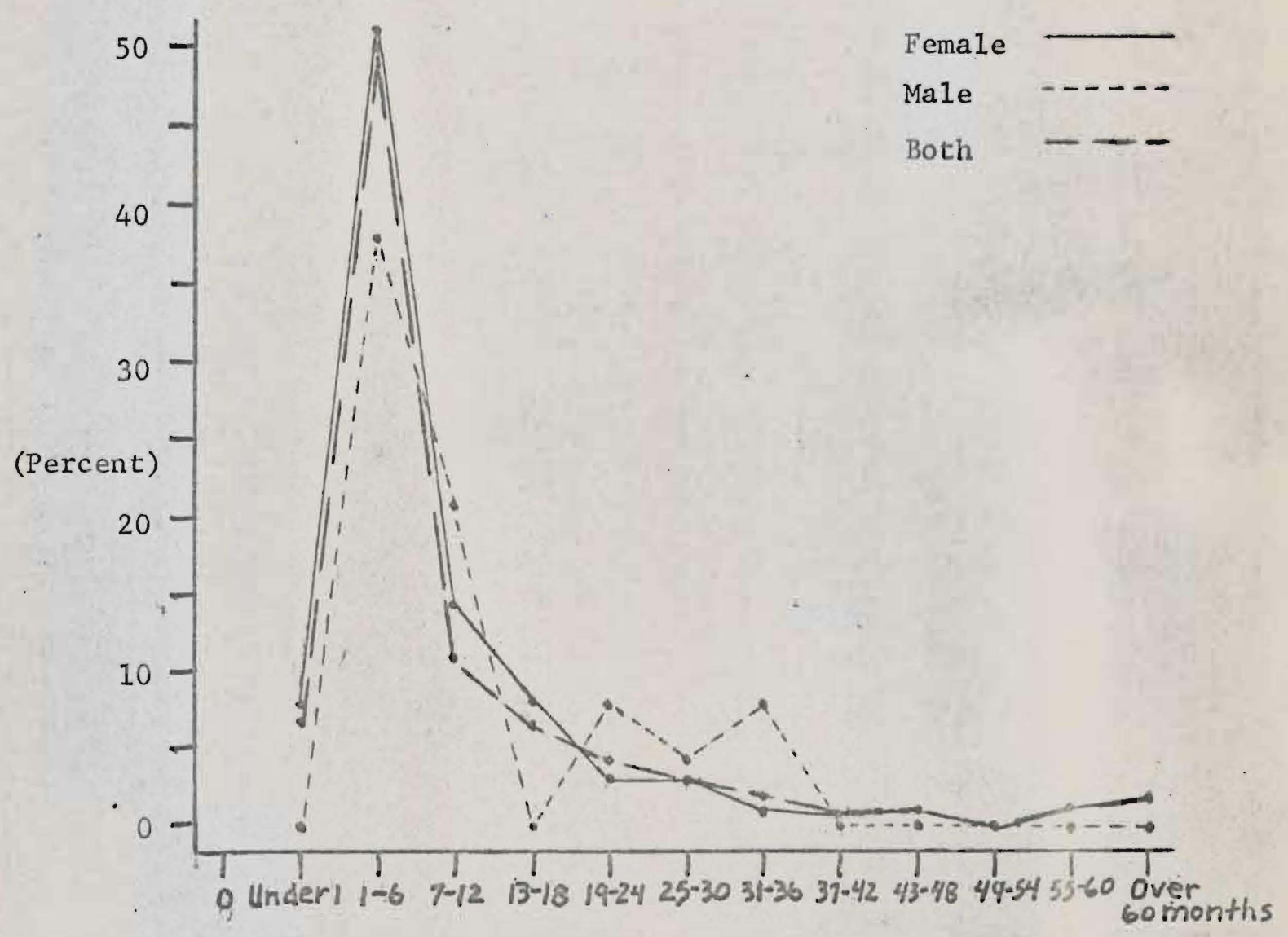

GRAPH 6

(Months)

\section{Separated - Number of Times (Question 16)}

(Table XXIII in Appendix) Graph 7 shows that (55\%) of the females and $(46 \%)$ of the males had been separated 1 to 2 times. Only (19.4\%) of the females and (20\%). of the males had been separated 3 or more times. One-fourth of the females and one-third of the males did not respond to this question. 
HOIN MANY TIMES SEPARATED

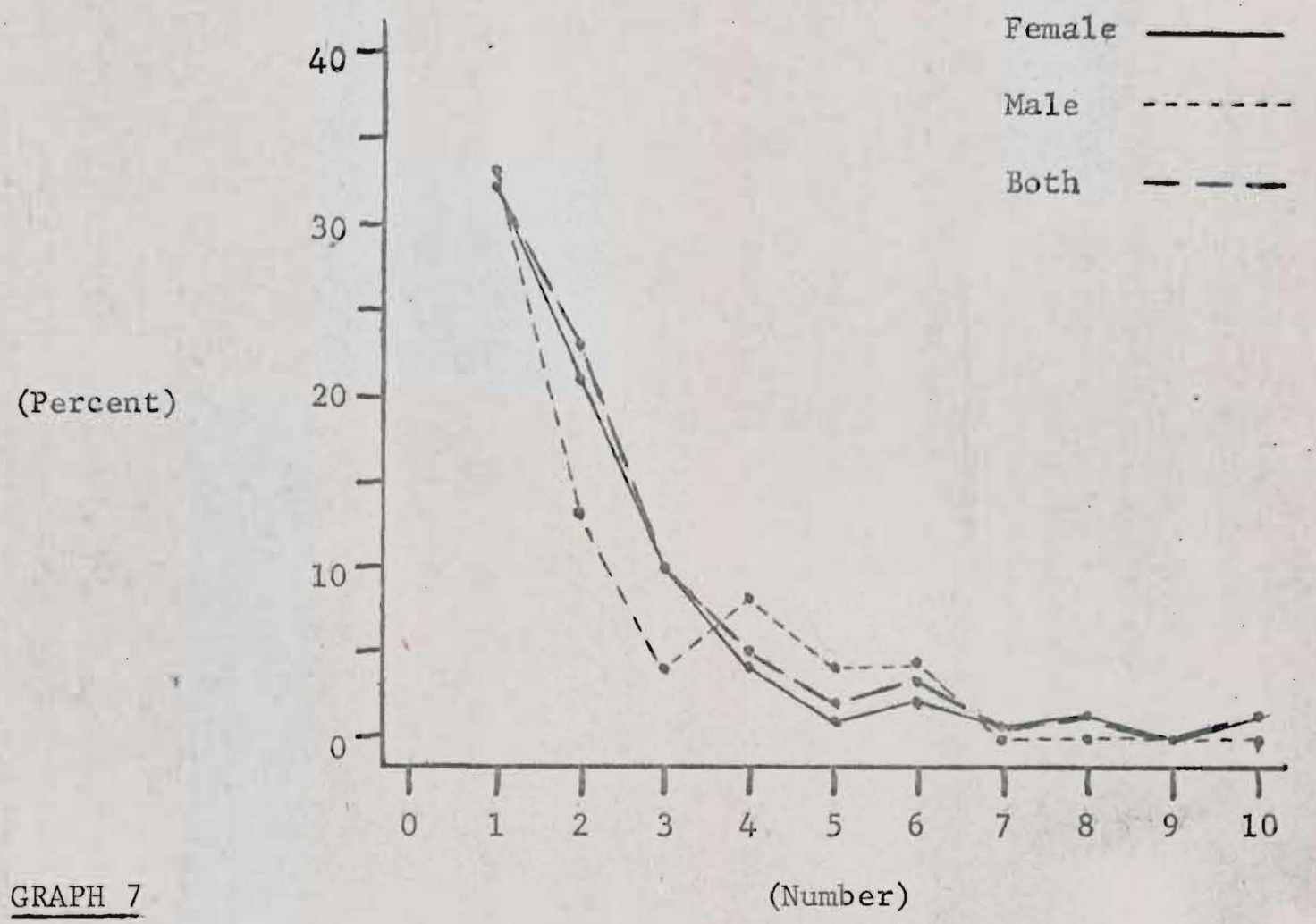

HELP WITH FAMTLY PROBLEMS (Question 17)

(Table XXIV in Appendix) The overwhelming response to this question was for divorce (females, $78 \%$ and males, $65 \%$ ) over all other alternatives to help with family problems.

Reasons for Divorce (Question 18)

(Table XXV in Appendix) The main reasons for wanting a divorce, as was indicated by both males and females, were: spouse drinks, $(50 \%)$; brutality, $(40 \%)$; arguments, (39\%); lack of affection, (34\%); and, spouse has boy/girlfriend, ( $32 \%)$.

Lack of affection (females, $34 \%$ and males, 35\%) and arguements (females, $39 \%$ and males, $38 \%$ ) were equally responded to by both 
sexes. The females showed some concern with both brutality (43\%) and spouse drinking (54\%); whereas the male responses (15\%) and and $(12 \%)$ did not indicate concern in these areas regarding their spouse. The males were more concerned about the wife having a boyfriend $(58 \%)$ than the females were about the husband having a girlfriend (29\%).

Spouse Providing for Children (Question 19)

(Tables XXVI \& XXVII in Appendix) A "No" response was given by both the males $(50 \%)$ and the females ( $65 \%$ ), indicating that the spouse was not providing for the children. Of those who answered "Yes", (females, 16\% and males, 31\%), one-half (50\%) of both male and female responses indicated that the spouse was providing money.

\section{Child Support (Question 20)}

(Tables XXVIII, XXIX \& XXX in Appendix) The data for the males was not considered for analysis and was not compiled on the tables for this question due to the fact that it was not applicable for them. This was not, however, indicated on the questionnaire as such. Fifty-seven percent of the females indicated that they wanted child support; (31\%) indicated that they did not want child support. Sixty-one percent of those who indicated that they wanted child support also said they would demand it.

The final part of this question: "If No: Is it because he won't pay anyway?" did not have a high enough response rate to be considered for analysis. 
Marriage Counseling (Question 21)

(Table XXXI in Appendix) Both males (56\%) and females (68\%) had never seen a marriage counselor; combining male and female responses, $(\dot{0} 6 \%)$ had never seen a marriage counselor.

\section{Legal Aid - Referral (Question 22)}

(Table XXXII in Appendix) Fourty-seven percent of the women had heard about Legal Aid from Welfare; (50\%) of the men had heard about Legal Aid from a friend. The least likely sources for women were the phone book and the spouse, and for men they were publicity and the phone book.

Legal Aid - Previous Contact (Question 23)

(Tables XXXIII and XXXIV in Appendix) Over two-thirds of the females ( $69 \%)$ and over one-half of the males (54\%) had never been to Legal Aid before. Of those who had previousiy been to Legal Aid (females, $29 \%$ and males, $35 \%$ ), the responses were split equally between coming for a divorce and for another legal problem.

\section{Legal Aid - Reason (Question 24)}

(Table XXXV in Appendix) There was an overwhelming response to this question indicating that most clients came to Legal Aid because of lack of money for a private attorney (females, .92\% and males, $77 \%$ ); combining both male and female responses, (91\%) came to Legal Aid for the above reason.

\section{Legal Aid - Transportation (Question 25)}

(Table XXXVI in Appendix) Both females (78\%) and males (58\%) 
either got to Legal Aid in their own car, with a friend, or on the bus. The spouse did not bring any of the clients.

\section{Agencies Seen in the Past Year (Question 26)}

(Table XXXVII in Appendix) The agencies most frequently contacted by the females were Welfare (60\%) and Food Stamps (51\%). Fourty-two percent of the males did not respond to this question; however, of those who did respond, (31\%) had contacted Food Stamps. 


\section{CONCLUS IONS}

It is possible to make certain assumptions, based on the data, regarding the four specific areas with which this study concerned itself. A resulting descriptive profile follows ${ }^{* *}$ :

1) Who the Client is; where he lives:

The typical client is a female, under 26 years of age, white, unemployed, on Welfare, receives $\$ 100-300$ per month, and has finished high school or its equivalent. She is renting a house or apartment in southeast Portland.

This client has 1 or 2 children between the ages of 1 and 5 , and these children are living with her. She denies that the children have suffered from the marriage, although she will admit some bad behavior.

She has been married only once, for a period of

1 to 5 years. She is presently separated, has been separated once or twice before, and has been separated this time for 1 to 6 months.

2) Why or if the client wants a divorce:

The client wants a divorce for the reasons of brutality, spouse drinking, arguments, and lack of affection. The husband is not providing for the children now, and she wants child support and will demand it. She has never been to a marriage counselor.

3) Why the client came to Legal Aid and his contacts with other agencies:

The client learned about Legal Aid from Welfare, and had no previous contacts there. She came to Legal Aid because of a lack of money for a private attorney. Transportation to Legal Aid was by car, bus, or a friend.

The agencies she has had most frequent contact with are Welfare and Food Stamps.

w*See Table XXXVIII in Appendix for profile list, percentages, and confidence levels. 
4) Whether the client has considered counsoling to help with his problems:

She was unwilling to soe a counsolor at the time of her first visit to Legal Aid. She did not request either counseling or advice, other than legal. 


\section{RECOMMENDATIONS}

\section{Family Counselor}

The Family Law Center is different from the previous domestic relations services offered by Legal Aid in that a social worker is available to render counseling services to the client at the time of the intake interview. According to J. V. McGoodwin, director, the clients are not requesting or utilizing this service.

Several reasons may account for the unwillingness by the clients to request or accept the services of a counselor. Some of these reasons include: 1) the emotional state of the client at the time of intake may render it impossible for him to see any alternative to his present situation except for the legal one; 2) the majority of the clients, as shown in this study, saw divorce as the only solution to their family problems at intake; and 3) poor people, in general, do not utilize professional counseling, or counseling in the traditional sense.

In spite of this, there is still a need for counseling for the many problems associated with the breakup of a family and its effect on the children, adjustment to divorce, and future planning for the client, his children, and his family.

In a study of the Family Law Center, examining its first seven months in operation, it was shown that only $60 \%$ of the clients showed up for the initial intake interview. On the basis 
of both 1) this low show-up rate, and 2) the client's unwillingness to utilize the counseling service at the time of intake, it would seem appropriate to make some changes concerning the use of the counselor at intake only。

We recommend, therefore, that counseling services be offered at one or both of the two delay points in the legal process at the Fantly Law Center. These two points are 1) before the initial interview, and 2) while waiting for "normal" paperwork to be done, after the initial interview. This could be accomplished at point 1) by mentioning counseling at the time of the initial phone contact with the client, sending informational brochures with the appointment letter, and personal contact by the counselor via the telephone or home visits. At point 2), again contact could be initiated by the counselor either by letter, telephone, or a home visit could be attempted.

Regardless of which method of contact, or at which point counseling is offered, it would certainly seem appropriate to attempt some other method than that which is presently being done for the reason that it has not proven effective.

\section{$\underline{\text { Location }}$}

Our study shows that the majority of the clients live in southeast Portland. At one point in this project, we had some concern about the location of the Family Law Center downtown and its accessibility to the clients. After further consideration of the transportation problem (many of the clients come to the Family Law Center by bus), we now concur with the decision to locate downtown. 
Although this location may be inconvenient for some, it is most convenient for the majority.

\section{Data Retrieval}

We feel that it is important to the Family Law Center, as it is to any service-offering agency, to have a systematic method for data retrieval. A well organized method for recovering data can save staff time, is necessary to document services and statistics for funding purposes, and is invaluable for use in ongoing planning and evaluation of the program.

The data furnished in the conclusions section of this study and Table XXXVIII in the Appendix, might appropriately be included in some type of data collection system. We, as social workers, feel that these results are important in a Family Law Center setting to be used at the discretion of Legal Aid, with the agency making the decision as to what data it feels as important and pertinent. Selection of and use of this data would be for future resource material; to better aid the clients, the Family Law Center, and the legal process; as well as the social worker functioning in a legal setting.

Some of the ways more efficient data retrieval might be accomplished are 1) additional data obtained on the buff card; 2) use of IBM cards; and 3) some type of card-sensing system. The mechanics of setting up a data-retrieval system, regardless of method used, is beyond the scope of this study and our expertise. However, more information alout various kinds of data collection systems can be obtained from many sources, if Legal Aid so desires. 
APPENDIX 
TABLE I

QUESTIONNAIRES

\begin{tabular}{lrr}
\hline & Number & $\%$ \\
\cline { 2 - 3 } Completed & 243 & 83 \\
Returned Blank & 28 & 9 \\
Not Returned & 22 & 8 \\
Total & 293 \\
\hline
\end{tabular}

TABLE II

SEX

\begin{tabular}{lrr}
\hline & Number & $\%$ \\
\cline { 2 - 3 } Female & 217 & 89 \\
Male & 26 & 11 \\
Total & 243 & \\
\hline
\end{tabular}

TABLE III

AGE

\begin{tabular}{|c|c|c|c|c|c|c|c|}
\hline \multirow[b]{2}{*}{ Years } & $\mathrm{N}$ & $\%$ & $\mathrm{~N}$ & $\%$ & $\mathrm{~N}$ & $\%$ & \\
\hline & \multicolumn{2}{|c|}{ Female } & \multicolumn{2}{|c|}{ Male } & \multicolumn{2}{|c|}{ Both } & \\
\hline $16-20$ & 48 & 22 & 0 & 0 & 48 & 20 & \\
\hline $21-25$ & 82 & 38 & 10 & 38 & 92 & 38 & \\
\hline $26-30$ & 30 & 14 & 7 & 27 & 37 & 15 & \\
\hline $31-35$ & 21 & 10 & 1 & 4 & 22 & 9 & \\
\hline $36-40$ & 15 & 7 & 1 & 4 & 16 & 7 & \\
\hline $4 I-45$ & 9 & 4 & 3 & 12 & 12 & 5 & \\
\hline $46-50$ & 5 & 2 & 1 & 4 & 6 & 2 & \\
\hline $51-55$ & 2 & 1 & 0 & 0 & 2 & 1 & \\
\hline $56-60$ & 1 & .4 & 0 & 0 & 1 & .4 & \\
\hline $61-65$ & 0 & 0 & 0 & 0 & 0 & 0 & \\
\hline $65-70$ & 2 & 1 & 2 & 8 & 4 & 2 & \\
\hline No Response & 2 & 1 & 1 & 4 & 3 & 1 & \\
\hline Total & 217 & & 26 & & 243 & & \\
\hline
\end{tabular}


TABLE IV

RACE

\begin{tabular}{|c|c|c|c|c|c|c|}
\hline \multirow[t]{2}{*}{ - } & $\underline{N}$ & $\%$ & $\mathrm{~N}$ & $\%$ & $\mathrm{~N}$ & $\%$ \\
\hline & \multicolumn{2}{|c|}{ Female } & \multicolumn{2}{|c|}{ Male } & \multicolumn{2}{|c|}{ Both } \\
\hline Black & 18 & 8 & 2 & 8 & 20 & 8 \\
\hline White & 193 & 89 & 22 & 85 & 215 & 88 \\
\hline Mexican & 0 & 0 & 0 & 0 & 0 & 0 \\
\hline Indian & 4 & 2 & 1 & 4 & 5 & 2 \\
\hline Oriental & 1 & .4 & 1 & 4 & 2 & 1 \\
\hline No Response & 1 & .4 & 0 & 0 & 1 & .4 \\
\hline Total & 217 & & 26 & & 243 & \\
\hline
\end{tabular}

TABLE V

EMPLOYED

\begin{tabular}{lrrrrrr}
\hline & $N$ & $\%$ & N & $\%$ & N & $\%$ \\
\cline { 2 - 6 } & \multicolumn{1}{c}{ Female } & Male & Both \\
\cline { 2 - 6 } & 45 & 21 & 6 & 23 & 51 & 21 \\
Yes & 165 & 76 & 20 & 78 & 185 & 76 \\
No & 7 & 3 & 0 & 0 & 7 & 3 \\
No Response & 217 & & 26 & & 243 & \\
Total & & & & & & \\
\hline
\end{tabular}

TABLE VI

ON WELFARE

\begin{tabular}{lrrrrrr} 
& N & $\%$ & N & $\%$ & N & $\%$ \\
\cline { 2 - 7 } & \multicolumn{1}{c}{ Female } & Male & Both \\
\hline Yes & 127 & 59 & 1 & 4 & 128 & 53 \\
No & 85 & 39 & 22 & 85 & 107 & 44 \\
No Response & 5 & 2 & 3 & 12 & 8 & 3 \\
Total & 217 & & 26 & & 243 & \\
\hline
\end{tabular}


TABLE VII

INCOME

\begin{tabular}{|c|c|c|c|c|c|c|}
\hline \multirow[b]{3}{*}{ None } & \multirow{2}{*}{\multicolumn{2}{|c|}{$\begin{array}{l}\mathrm{N} \% \\
\text { Female } \\
\end{array}$}} & \multirow{2}{*}{\multicolumn{2}{|c|}{$\begin{array}{l}\mathrm{N} \% \\
\text { Male }\end{array}$}} & \multirow{2}{*}{\multicolumn{2}{|c|}{ N $\%$}} \\
\hline & & & & & & \\
\hline & 14 & 6 & 4 & 15 & 18 & 7 \\
\hline Under $\$ 100$ & 13 & 6 & 1 & 4 & 14 & 6 \\
\hline$\$ 100-199$ & 76 & 35 & 6 & 23 & 82 & 34 \\
\hline$\$ 200-299$ & 53 & 24 & 7 & 27 & 60 & 25 \\
\hline$\$ 300-399$ & 11 & 5 & 2 & 8 & 12 & 5 \\
\hline$\$ 400-499$ & 1 & .4 & 0 & 0 & 1 & .4 \\
\hline$\$ 500-599$ & 0 & 0 & 0 & 0 & 0 & 0 \\
\hline$\$ 500-599$ & 0 & 0 & 0 & 0 & 0 & 0 \\
\hline$\$ 700-799$ & 0 & 0 & 0 & 0 & 0 & 0 \\
\hline$\$ 300-899$ & 0 & 0 & 0 & 0 & 0 & 0 \\
\hline$\$ 900-999$ & 1 & .4 & 0 & 0 & 1. & .4 \\
\hline No Response & 48 & 22 & 6 & 23 & 54 & 22 \\
\hline Total & 217 & & 26 & & 243 & \\
\hline
\end{tabular}

TABLE VIII

EDUCATION

(part 1)

\begin{tabular}{|c|c|c|c|c|c|c|}
\hline \multirow[b]{3}{*}{ Grade School } & \multirow{2}{*}{\multicolumn{2}{|c|}{$\begin{array}{l}\mathrm{N} \quad \% \\
\text { Female }\end{array}$}} & \multirow{2}{*}{\multicolumn{2}{|c|}{$\begin{array}{l}\text { N } \% \\
\text { Male }\end{array}$}} & \multirow{2}{*}{\multicolumn{2}{|c|}{$\begin{array}{l}\text { N } \% \\
\text { Both } \\
\end{array}$}} \\
\hline & & & & & & \\
\hline & 44 & 20 & 4 & 15 & 48 & 20 \\
\hline High School & 129 & 59 & 10 & 38 & 139 & 57 \\
\hline College & 20 & 9 & 5 & 19 & 25 & 10 \\
\hline GED & 12 & 6 & 7 & 27 & 19 & 8 \\
\hline No Response & 12 & 6 & 0 & 0 & 12 & 5 \\
\hline Total & 217 & & 26 & & 243 & \\
\hline
\end{tabular}


TABLE IX

EDUCATION

(part 2)

\begin{tabular}{|c|c|c|c|c|c|c|}
\hline & $\underline{\mathrm{N}}$ & $\%$ & $\mathrm{~N}$ & $\%$ & $\mathrm{~N}$ & $\%$ \\
\hline & \multicolumn{2}{|c|}{ Female } & \multicolumn{2}{|c|}{ Male } & \multicolumn{2}{|c|}{ Both } \\
\hline CEP training & 5 & 2 & 0 & 0 & 5 & 2 \\
\hline Voc. training & 9 & 4 & 0 & 0 & 9 & 4 \\
\hline Bus. School & 13 & 6 & 1 & 4 & 14 & 6 \\
\hline Trade School & 4 & 2 & 0 & 0 & 4 & 2 \\
\hline *other & 0 & 0 & 1 & 4 & 1 & .4 \\
\hline No Response & 186 & 86 & 24 & 92 & 210 & 86 \\
\hline Total & 217 & & 26 & & 243 & \\
\hline
\end{tabular}

*other---Military

TABLE $X$

WHERE LIVING

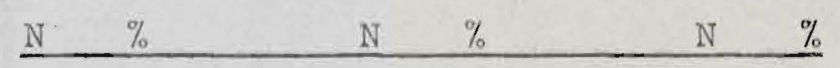

Female Male Both

$\begin{array}{lrrrrrr}\text { Renting Apt. } & 89 & 41 & 10 & 38 & 99 & 41 \\ \text { Renting House } & 75 & 35 & 7 & 27 & 82 & 34 \\ \text { Owns Home } & 11 & 5 & 2 & 8 & 13 & 5 \\ \text { No Response } & 42 & 19 & 7 & 27 & 49 & 20 \\ \text { Total } & 217 & & 26 & & 243\end{array}$


TABLE XI

WHO LIVING WITH NOW

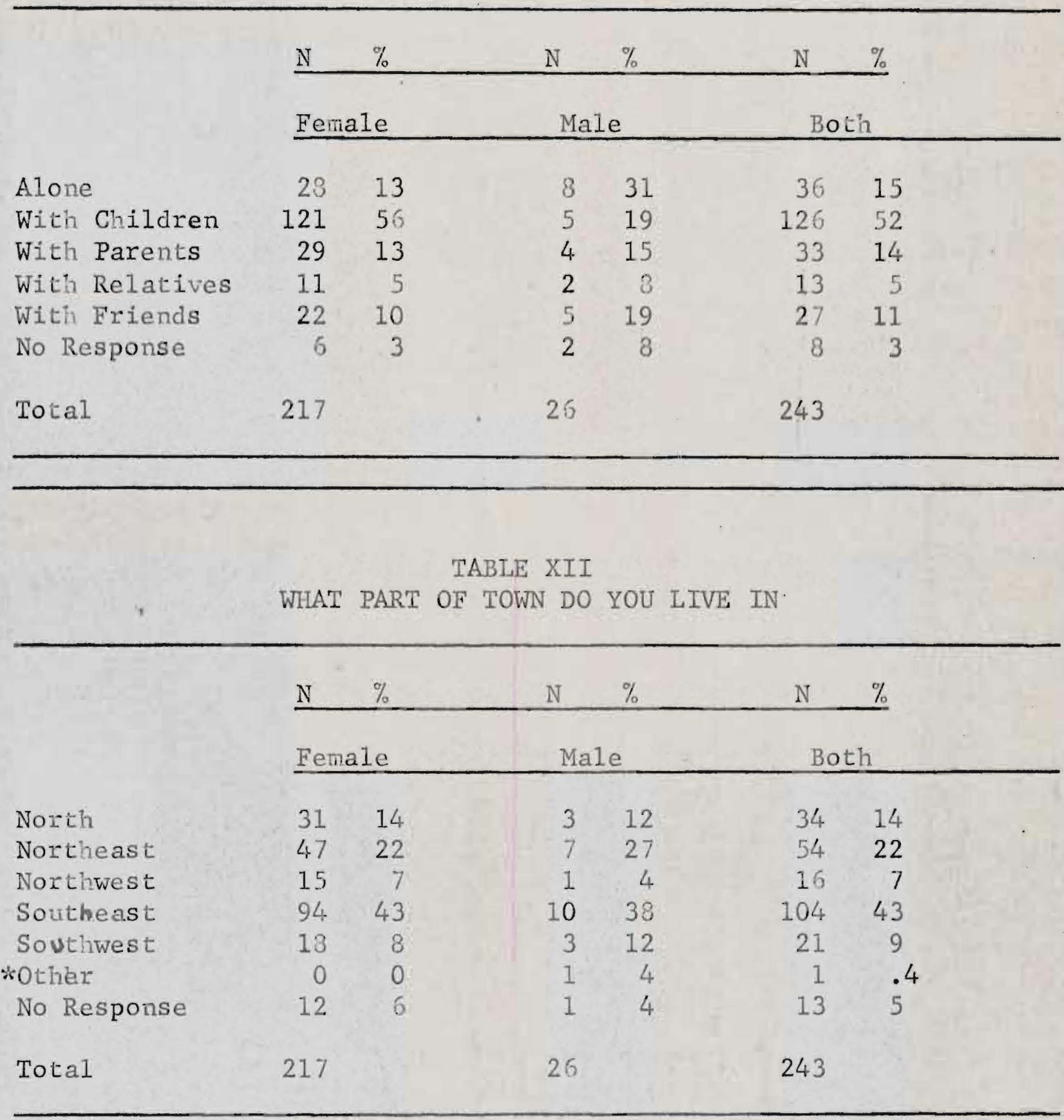

*Other-movt of Town 
TABLE XIII

AGES OF CHILDREN

(part 1)

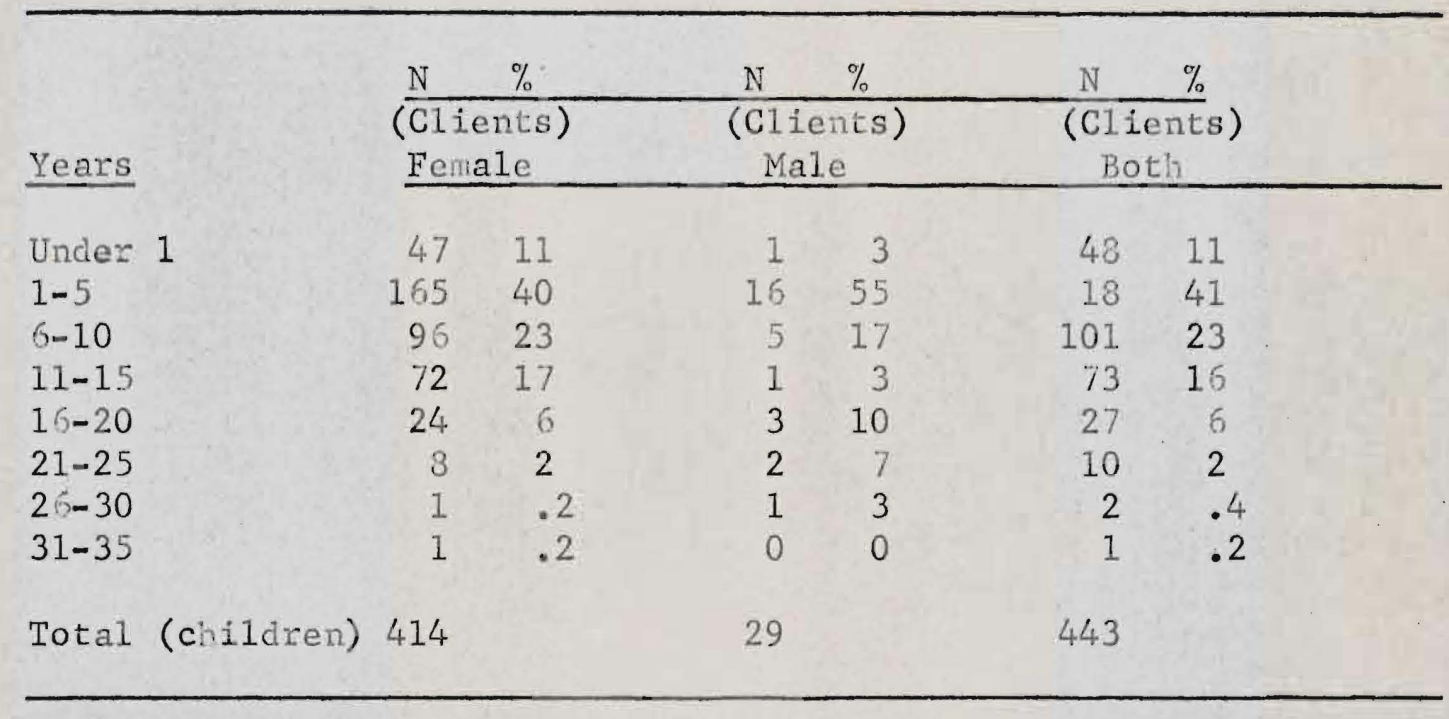

TABLE XIV

NUMBER OF CHILDREN IN FAMILY

(part 2)

\begin{tabular}{|c|c|c|c|c|c|c|c|}
\hline \multirow[b]{2}{*}{ None } & \multicolumn{2}{|c|}{$\begin{array}{l}\frac{\mathrm{N} \quad \%}{\text { (Clients) }} \\
\text { Female }\end{array}$} & \multicolumn{2}{|c|}{$\begin{array}{l}\mathrm{N} \quad \frac{\%}{(\mathrm{Clients})} \\
\text { Male }\end{array}$} & \multicolumn{2}{|c|}{$\begin{array}{l}\text { (Clients) } \\
\text { Both } \\
\end{array}$} & \\
\hline & 14 & 6 & 7 & 27 & 21 & 9 & \\
\hline 1 child & 65 & 30 & 7 & 27 & 72 & 30 & \\
\hline 2 children & 49 & 23 & 4 & 15 & 53 & 22 & \\
\hline $3 \quad 11$ & 41 & 19 & 2 & 8 & 43 & 18 & \\
\hline 4 & 14 & 6 & 2 & 8 & 15 & 7 & \\
\hline 5 & 7 & 3 & 0 & 0 & 7 & 3 & \\
\hline 611 & 3 & 1 & 0 & 0 & 3 & 1 & \\
\hline 711 & 0 & 0 & 0 & 0 & 0 & 0 & \\
\hline 3 & 0 & 0 & 0 & 0 & 0 & 0 & \\
\hline $9 \quad 11$ & 1 & .4 & 0 & 0 & 1 & .4 & \\
\hline *ther & 1 & .4 & 0 & 0 & 1 & .4 & \\
\hline No Response & 22 & 10 & 4 & 15 & 26 & 11 & \\
\hline Total & 217 & & 26 & & 243 & & \\
\hline
\end{tabular}

*other---Pregnant 
TABLE XV

WHERE ARE CHILDREN LIVING NOW

\begin{tabular}{|c|c|c|c|c|c|c|}
\hline & $(n=$ & 17) & & & $(n=$ & 43) \\
\hline & N & $\%$ & $\mathrm{~N}$ & $\%$ & $\mathrm{~N}$ & $\%$ \\
\hline & Fen & & & & & \\
\hline With You & 167 & 77 & 6 & 29 & 173 & 70 \\
\hline With Spouse & 10 & 5 & 8 & 38 & 18 & 7 \\
\hline Grandparents & 6 & 3 & 1 & 5 & 7 & 3 \\
\hline Other Relatives & 3 & 1 & 1 & 5 & 4 & 2 \\
\hline Friends & 0 & 0 & 0 & 0 & 0 & 0 \\
\hline Foster Home & 8 & 4 & 0 & 0 & 8 & 3 \\
\hline Adopted & 1 & .4 & 1 & 5 & 2 & 1 \\
\hline *Other & 1 & .4 & 0 & 0 & 1 & .4 \\
\hline No Response & 36 & 17 & 10 & 38 & 46 & 15 \\
\hline Total (Response & 232 & & 27 & & 259 & \\
\hline
\end{tabular}

*Other--married

TABLE XVI

HAVE CHILDREN SUFFERED FROM THIS MARRIAGE (part 1)

\begin{tabular}{|c|c|c|c|c|c|c|c|}
\hline \multirow[b]{3}{*}{ Yes } & $\mathrm{N}$ & $\%$ & N & $\%$ & $\mathrm{~N}$ & \multirow[t]{2}{*}{$\%$} & \\
\hline & \multicolumn{2}{|c|}{ Fenale } & \multicolumn{2}{|c|}{ Male } & Both & & \\
\hline & 75 & 35 & 6 & 23 & 81 & 33 & \\
\hline No & 111 & 51 & 15 & 58 & 126 & 52 & \\
\hline No Response & 31 & 14 & 5 & 19 & 36 & 15 & . \\
\hline Total & 217 & & 26 & & 243 & & \\
\hline
\end{tabular}


TABLE XVII

IF YES : HOW

(part 2)

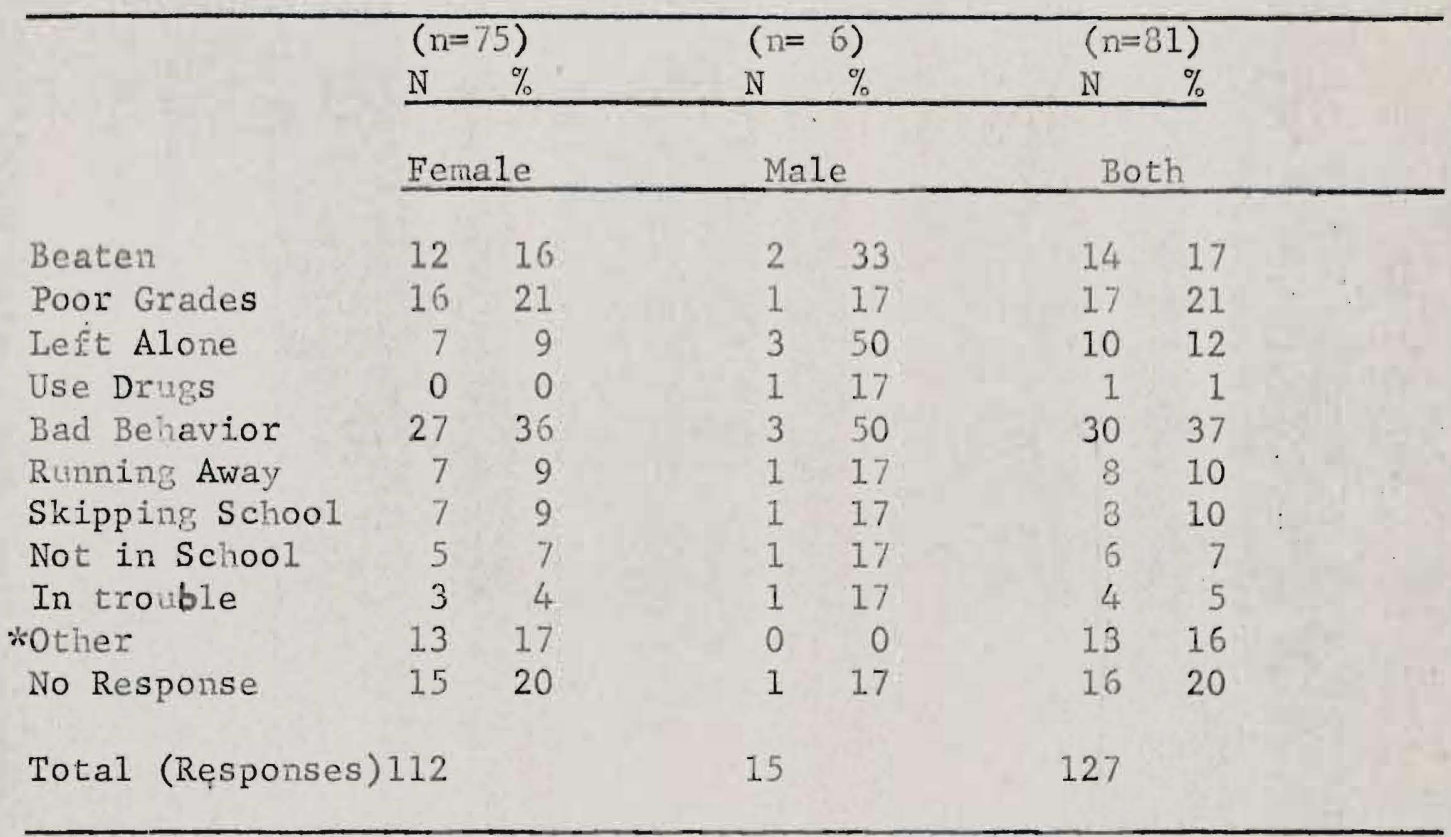

*other---Scared, 1; Nerves, 1; Mistreated, 3; Enotional1y or mentally upsetting (speech problem, seeing fighting, etc.), 5; Unsettled (Lack of hamony), 2; Unhappy, 1.

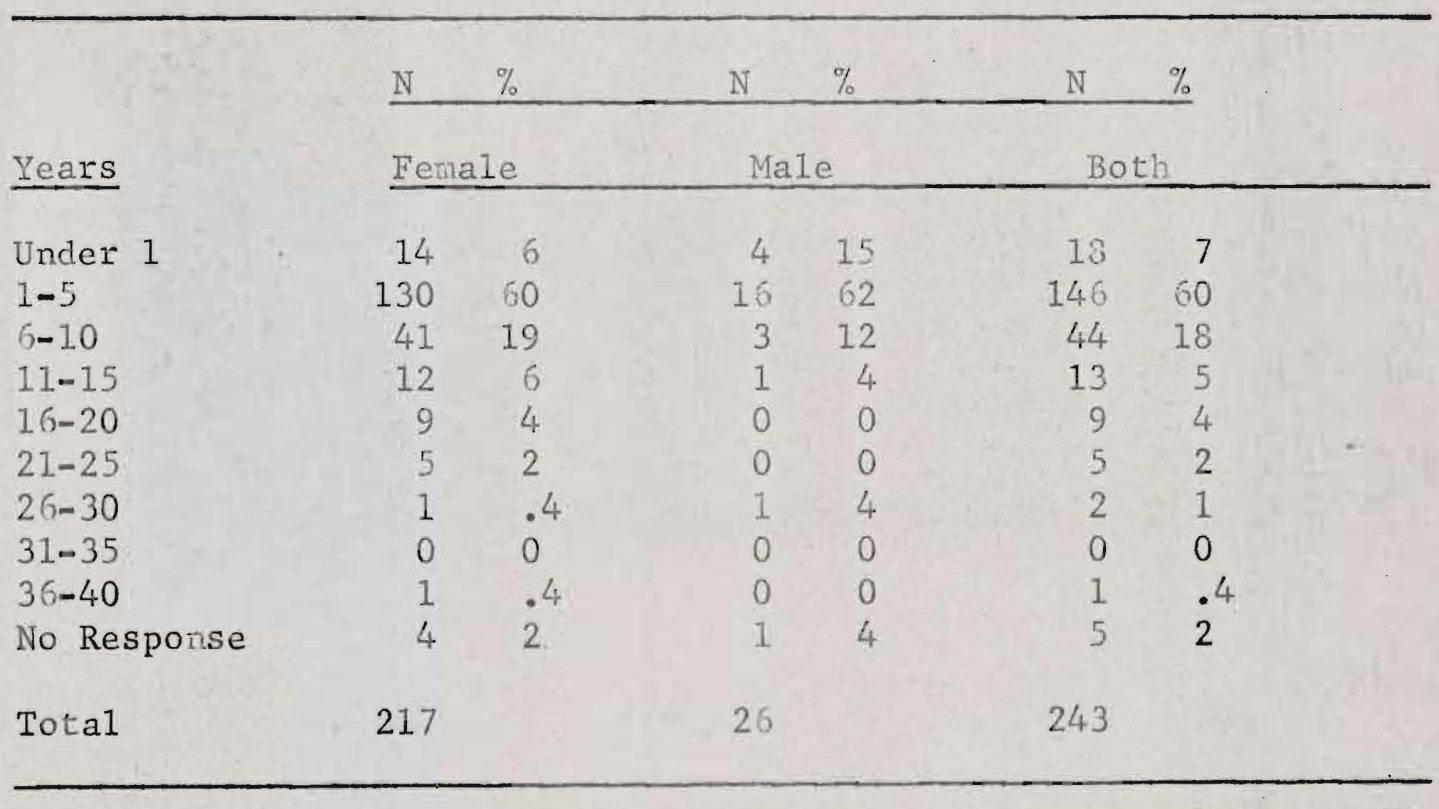


TABLE XIX

NUMBER OF TIMES MARRIED

\begin{tabular}{lrrrrrrr}
\hline & N & $\%$ & N & $\%$ & N & $\%$ \\
\cline { 2 - 7 } & Female & Male & Both \\
\hline & 153 & 71 & 16 & 62 & 169 & 70 \\
1 & 40 & 18 & 6 & 23 & 46 & 19 \\
2 & 15 & 7 & 1 & 4 & 16 & 7 \\
3 & 2 & 1 & 0 & 0 & 2 & 1 \\
5 & 1 & .4 & 0 & 0 & 1 & .4 \\
No Response & 6 & 3 & 3 & 12 & 9 & 4 \\
Total & & & & & & &
\end{tabular}

TABLE XX

ARE YOU SEPARATED NOW

(part 1)

\begin{tabular}{lrrrrrrr}
\hline & N & $\%$ & N & $\%$ & N & $\%$ \\
\cline { 2 - 6 } & Female & Male & Both \\
\hline Yes & 204 & 94 & 24 & 92 & 228 & 94 \\
No & 11 & 5 & 1 & 4 & 12 & 5 \\
No Response & 2 & 1 & 1 & 4 & 3 & 1 \\
Total & 217 & & 26 & & 243 & \\
\hline
\end{tabular}


TABLE XXI

HOW LONG THIS TIME

(part 2)

\begin{tabular}{|c|c|c|c|c|c|c|}
\hline & $\mathrm{N}$ & $\%$ & $\mathrm{~N}$ & $\%$ & $\mathrm{~N}$ & $\%$ \\
\hline Months & \multicolumn{2}{|c|}{ Female } & \multicolumn{2}{|c|}{ Male } & \multicolumn{2}{|c|}{ Both } \\
\hline Under 1 & 17 & 8 & 0 & 0 & 17 & 7 \\
\hline $1-6$ & 104 & 51 & 9 & 38 & 115 & 50 \\
\hline $7-12$ & 29 & 14 & 5 & 21 & 34 & 11 \\
\hline $13-18$ & 16 & 8 & 0 & 0 & 16 & 7 \\
\hline $19-24$ & 6 & 3 & 2 & 8 & 8 & 4 \\
\hline $25-30$ & 6 & 3 & 1 & 4 & 7 & 3 \\
\hline $31-36$ & 3 & 1 & 2 & 8 & 5 & 2 \\
\hline $37-42$ & 1 & .4 & 0 & 0 & 1 & .4 \\
\hline $43-48$ & 2 & $i$ & 0 & 0 & 2 & 1 \\
\hline 49-54 & 0 & 0 & 0 & 0 & 0 & 0 \\
\hline $55-60$ & 3 & 1 & 0 & 0 & 3 & 1 \\
\hline Over 60 (5 yrs.) & 5 & 2 & 0 & 0 & 5 & 2 \\
\hline No Response & 12 & 6 & 5 & 21 & 17 & 7 \\
\hline Total & 204 & & 24 & & 228 & \\
\hline
\end{tabular}

TABLE XXII

WHO LEFT THIS TIME

(part 3)

\begin{tabular}{|c|c|c|c|c|c|c|}
\hline \multirow[b]{3}{*}{ Self } & \multicolumn{2}{|l|}{$\mathrm{N}$} & \multicolumn{2}{|l|}{$\mathrm{N}$} & \multicolumn{2}{|l|}{$\mathrm{N}$} \\
\hline & \multicolumn{2}{|c|}{ Female } & \multicolumn{2}{|c|}{ Male } & \multicolumn{2}{|c|}{ Both } \\
\hline & 93 & 46 & 7 & 29 & 100 & 44 \\
\hline Spouse & 89 & 44 & 12 & 50 & 101 & 44 \\
\hline *other & 7 & 3 & 1 & 4 & 8 & 4 \\
\hline No Response & 15 & 7 & 4 & 17 & 19 & 8 \\
\hline Total & 204 & & 24 & & 228 & \\
\hline
\end{tabular}

*other---Both Parties Left 
TABLE XXIII

HOW MANY TIMES SEPARATED

(part 4)

\begin{tabular}{|c|c|c|c|c|c|c|}
\hline & $\underline{N}$ & $\%$ & $\mathrm{~N}$ & $\%$ & $\mathrm{~N}$ & $\%$ \\
\hline & \multicolumn{2}{|c|}{ Female } & \multicolumn{2}{|c|}{ Male } & \multicolumn{2}{|c|}{ Both } \\
\hline 1 & 65 & 32 & 8 & 33 & 73 & 32 \\
\hline 2 & 46 & 23 & 3 & 13 & 49 & 21 \\
\hline 3 & 21 & 10 & 1 & 4 & 22 & 10 \\
\hline 4 & 9 & 4 & 2 & 8 & 11 & 5 \\
\hline 5. & 3 & 1 & 1 & 4 & 4 & 2 \\
\hline 6 & 5 & 2 & 1 & 4 & 6 & 3 \\
\hline 7 & 1 & .4 & 0 & 0 & 1 & .4 \\
\hline 8 & 2 & 1 & 0 & 0 & 2 & 1 \\
\hline 9 & 0 & 0 & 0 & 0 & 0 & 0 \\
\hline 10 & 2 & 1 & 0 & 0 & 2 & 1 \\
\hline No Response & 50 & 25 & 8 & 33 & 58 & 25 \\
\hline Total & 204 & & 24 & & 228 & \\
\hline
\end{tabular}

TABLE XXIV

WHAT HAVE YOU THOUGHT ABOUT TO HELP WITH YOUR FAMILY PROBLEMS

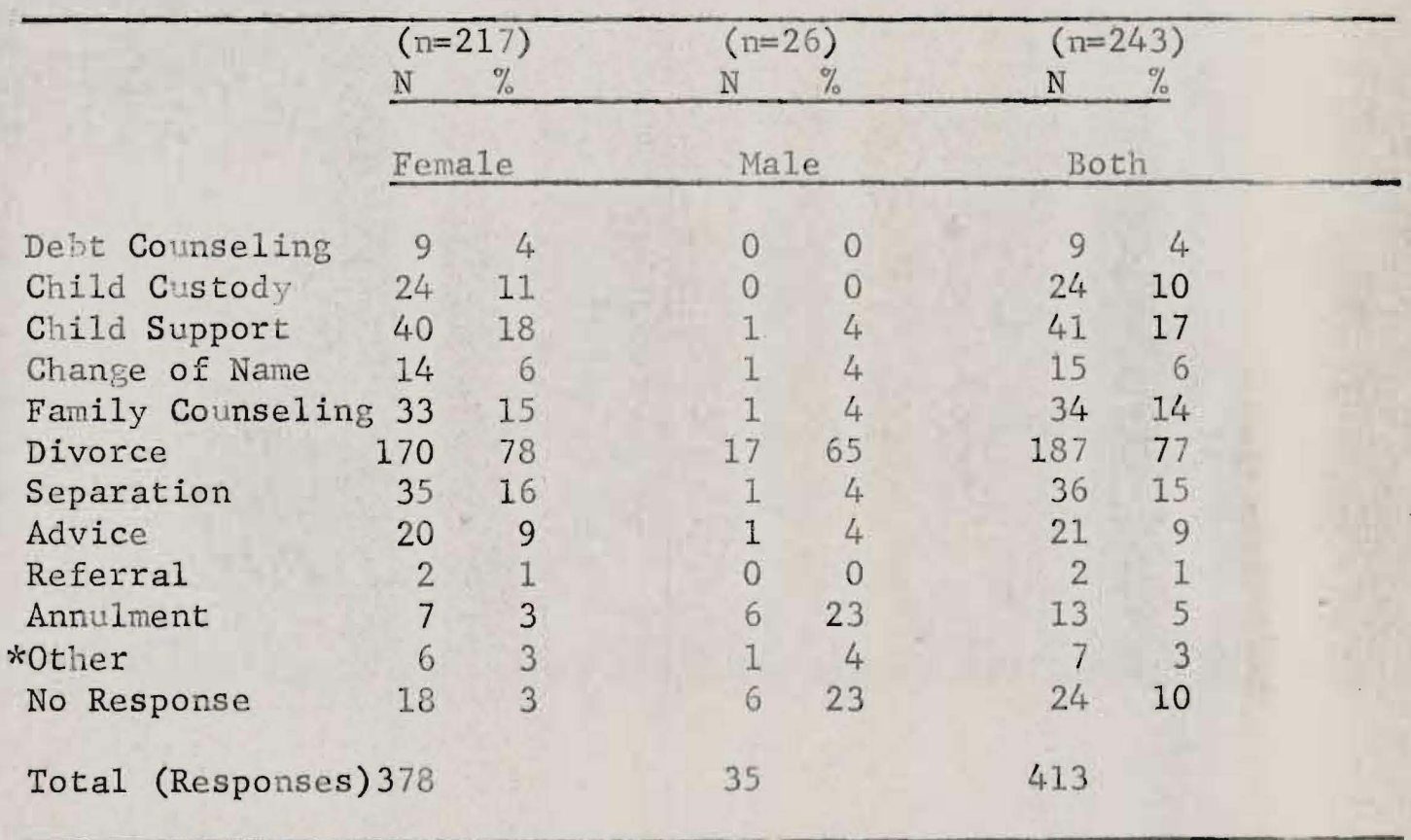

*Other--minister, 1; psychiatrist or counselor, 2 (1 male): P.S.U. Counseling Service, 2; Return to School, 1; "Work them out ourselves", 1. 
TABLE XXV

IF YOU ARE CONSIDERING A DIVORCE: WHY

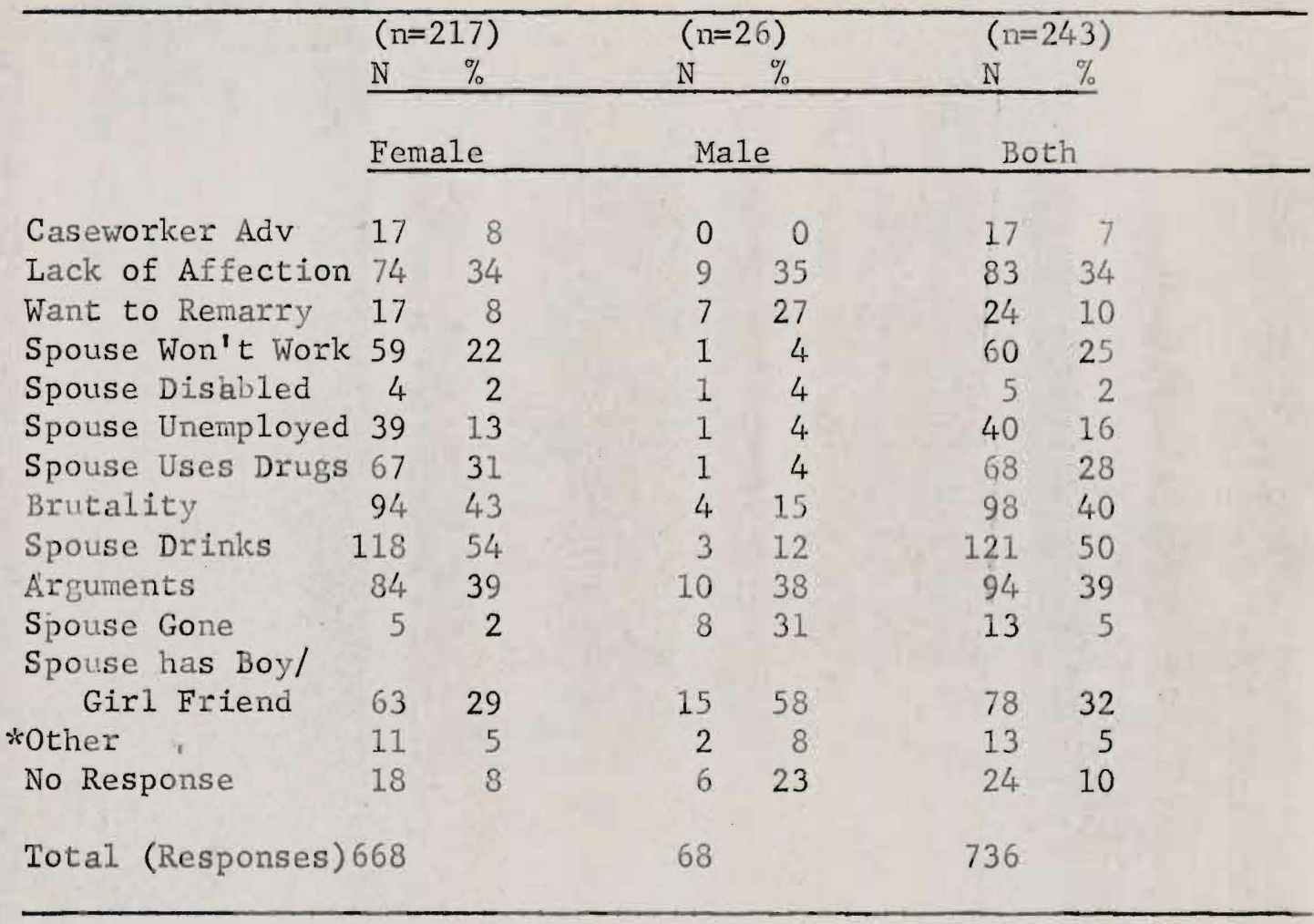

*Other-aGamie, 2 (1 male); Incompatibility, 4; Doctor Advised, 1; Spohse Married, 3 ( 1 male); Spouse in Jail, 1; "Won't Keep a Job", 1; "Spouse doesn't want me", 1.

TABLE XXVI

IS SPOUSE PROVIDING FOR CHILDREN NOW

(part 1)

\begin{tabular}{|c|c|c|c|c|c|c|c|}
\hline \multirow{5}{*}{$\begin{array}{l}\text { Yes } \\
\text { No } \\
\text { No Response }\end{array}$} & $\underline{N}$ & $\%$ & $\mathrm{~N}$ & $\%$ & $\mathrm{~N}$ & $\%$ & \\
\hline & \multicolumn{2}{|c|}{ Female } & \multicolumn{2}{|c|}{ Male } & \multicolumn{2}{|c|}{ Both } & \\
\hline & 34 & 16 & 8 & 31 & 42 & 17 & \\
\hline & 141 & 65 & 5 & 19 & 146 & 60 & \\
\hline & 42 & 19 & 13 & 50 & 55 & 23 & \\
\hline Total & 217 & & 20 & & 243 & & \\
\hline
\end{tabular}


TABLE XXVII

IF YES : HOW

(part 2)

\begin{tabular}{|c|c|c|c|c|c|c|}
\hline & $(n$ & & & & $(n=$ & \\
\hline & $\mathrm{N}$ & $\%$ & $\mathrm{~N}$ & $\%$ & & $\%$ \\
\hline & $\mathrm{Fe}$ & & & & & \\
\hline Clothing & 8 & 24 & $\angle$ & 50 & 12 & 29 \\
\hline Food & 10 & 29 & 5 & 63 & 15 & 36 \\
\hline Money & 17 & 50 & 4 & 50 & 21 & 50 \\
\hline Transportation & 2 & 6 & 3 & 38 & 5 & 12 \\
\hline Entertainment & 3 & 9 & 1 & 13 & 4 & 10 \\
\hline Housing & 10 & 29 & $<$ & 50 & 14 & 33 \\
\hline No Response & 7 & 21 & 1 & 13 & 8 & 19 \\
\hline Total (Responses) & 57 & & 22 & & 79 & \\
\hline
\end{tabular}

TABLE XXVIII

DO YOU WANT CHILD SUPPORT

(part 1)

N $\quad \%$

Female

$\begin{array}{lrr}\text { Yes } & 123 & 57 \\ \text { No } & 68 & 31 \\ \text { No Response } & 26 & 12 \\ & & \\ \text { Total } & 217 & \end{array}$

IF YES: WILL YOU DEMAND SUPPORT

(part 2)

N $\%$

Female

$\begin{array}{lll}\text { Yes } & 75 & 51 \\ \text { No } & 26 & 31 \\ \text { No Response } & 12 & 18\end{array}$

Total 
TABLE XXX

IF NO: IS IT BECAUSE HE WON'T PAY ANYWAY

(part 3)

$\mathrm{N} \quad \%$

Female

$\begin{array}{lll}\text { Yes } & 23 & 34 \\ \text { No } & 20 & 29 \\ \text { No Response } & 25 & 37 \\ & & \\ \text { Total } & 68 & \end{array}$

TABLE XXXI

HAVE YOU EVER SEEN A MARRIAGE COUNSELOR

\begin{tabular}{lrrrrrr}
\hline & N & $\%$ & N & $\%$ & N & $\%$ \\
\cline { 2 - 6 } & Female & Male & Both \\
\hline Yes & 56 & 26 & 4 & 15 & 60 & 25 \\
No & 147 & 68 & 14 & 54 & 161 & 66 \\
No Response & 14 & 6 & 8 & 31 & 22 & 9 \\
Total & 217 & & 26 & & 243 & \\
\hline
\end{tabular}

TABLE XXXII

HOW DID YOU KNOW ABOUT LEGAL AID

\begin{tabular}{|c|c|c|c|c|c|c|}
\hline & $(n=$ & 17) & & & $(n=$ & 43) \\
\hline & & $\%$ & $\mathrm{~N}$ & $\%$ & N & $\%$ \\
\hline & Fem & & & & & \\
\hline Welfare & 103 & 47 & 2 & 8 & 105 & 43 \\
\hline Friend & 62 & 29 & 13 & 50 & 75 & 31 \\
\hline Phone Book & 6 & 3 & 0 & 0 & 6 & 2 \\
\hline Spouse & 3 & 1 & 2 & 8 & 5 & 2 \\
\hline Publicity & 34 & 16 & 1 & 4 & 35 & 14 \\
\hline Relatives & 30 & 14 & 2 & 8 & 32 & 13 \\
\hline Private Attorney & 15 & 7 & 2 & 8 & 17 & 7 \\
\hline *other & 19 & 9 & 2 & 8 & 21 & 9 \\
\hline No Response & 8 & 4 & 5 & 19 & 13 & 5 \\
\hline Total (Responses) & 280 & & 29 & & 319 & \\
\hline
\end{tabular}


*other-m-Mental Health Psychologist, 5 (1 male); Mr. Norm Monroe, 10 (1 male); Legal Aid Attorney, 1; Social Worker, 1; Domestic Relations Counselor, 1; "Been here before", 1; Police, 1; Counselor, 1.

TABLE XXXIII

HAVE YOU EVER BEEN TO LEGAL AID BEFORE (part 1)

\begin{tabular}{|c|c|c|c|c|c|c|}
\hline & $\underline{N}$ & $\%$ & $\mathrm{~N}$ & $\%$ & N & $\%$ \\
\hline & \multicolumn{2}{|c|}{ Fernale } & \multicolumn{2}{|c|}{ Male } & \multicolumn{2}{|c|}{ Both } \\
\hline Yes & 64 & 29 & 9 & 35 & 73 & 30 \\
\hline No & 149 & 69 & 14 & 54 & 163 & 67 \\
\hline No Response & 4 & 2 & 3 & 12 & 7 & 3 \\
\hline Total, & 217 & & 26 & & 243 & \\
\hline
\end{tabular}

TABLE XXXIV

IF YES : WHY (part 2)

\begin{tabular}{|c|c|c|c|c|c|c|}
\hline & $(n$ & & & & & \\
\hline & $\mathrm{N}$ & $\%$ & & $\%$ & & $\%$ \\
\hline & $\underline{\mathrm{Fe}}$ & & & & & \\
\hline $\begin{array}{l}\text { Divorce } \\
\text { Other Legal }\end{array}$ & 30 & 47 & 4 & 44 & 34 & 47 \\
\hline Problem & 33 & 52 & 5 & 56 & 38 & 52 \\
\hline No Response & 27 & 42 & 1 & 11 & 28 & 38 \\
\hline Total (Responses) & 67 & & 12 & & 77 & \\
\hline
\end{tabular}


TABLE XXXV

DID YOU COME TO LEGAL AID BECAUSE OF LACK OF MONEY FOR A PRIVATE ATTORNEY

\begin{tabular}{|c|c|c|c|c|c|c|}
\hline & $\underline{N}$ & $\%$ & $\mathrm{~N}$ & $\%$ & $\mathrm{~N}$ & $\%$ \\
\hline & \multicolumn{2}{|c|}{ Female } & \multicolumn{2}{|c|}{ Male } & \multicolumn{2}{|c|}{ Both } \\
\hline Yes & 200 & 92 & 20 & 77 & 220 & 91 \\
\hline No & 7 & 3 & 0 & 0 & 7 & 3 \\
\hline No Response & 10 & 5 & 6 & 23 & 16 & 7 \\
\hline Total & 217 & & 26 & & 243 & \\
\hline
\end{tabular}

TABLE XXXVI

HOW DID YOU GET TO LEGAL AID TODAY

\begin{tabular}{|c|c|c|c|c|c|c|}
\hline \multirow[b]{3}{*}{ Own Car } & & $\%$ & $\mathrm{~N}$ & $\%$ & $\mathrm{~N}$ & \multirow[t]{2}{*}{$\%$} \\
\hline & \multicolumn{2}{|c|}{ Eenale } & \multicolumn{2}{|c|}{ Male } & Both & \\
\hline & 54 & 25 & 5 & 19 & 59 & 24 \\
\hline Taxicab & 4 & 2 & 1 & 4 & 5 & 2 \\
\hline Friend & 63 & 29 & 7 & 27 & 70 & 29 \\
\hline Bus & 53 & 24 & 3 & 12 & 56 & 23 \\
\hline Spouse Brought & 0 & 0 & 0 & 0 & 0 & 0 \\
\hline Walked & 3 & 1 & 2 & 8 & 5 & 2 \\
\hline Relative & 23 & 11 & 2 & 8 & 25 & 10 \\
\hline *other & 10 & 5 & 0 & 0 & 10 & 4 \\
\hline No Response & 4 & 3 & 4 & 23 & 13 & 5 \\
\hline Total & 217 & & 26 & & 243 & \\
\hline
\end{tabular}

*Other---Borrowed Car, 4; Bike, 3; Agency Car, 2; Pick-up, 1. 
TABLE XXXVII

WHICH AGENCIES HAVE YOU SEEN IN THE PAST YEAR

\begin{tabular}{|c|c|c|c|c|c|c|}
\hline & $(n=$ & 17) & $(n=$ & & $(n=$ & 43) \\
\hline & $\mathrm{N}$ & $\%$ & $\mathrm{~N}$ & $\%$ & $\mathrm{~N}$ & $\%$ \\
\hline & $\underline{\mathrm{Fem}}$ & & $\mathrm{Ma}$ & & & \\
\hline Welfare & 131 & 60 & 4 & 15 & 135 & 56 \\
\hline Juvenile & & & & & & \\
\hline Detention & 9 & 4 & 2 & 8 & 11 & 5 \\
\hline Juvenile Court & 12 & 6 & 1 & 4 & 13 & 5 \\
\hline Other Court & 4 & 2 & 0 & 0 & 4 & 2 \\
\hline Probation & 2 & 1 & 1 & 4 & 3 & 1 \\
\hline Parole & 3 & 1 & 0 & 0 & 3 & 1 \\
\hline Food Stamps & 111 & 51 & 8 & 31 & 119 & 49 \\
\hline Mental Health & 20 & 9 & 2 & 8 & 22 & 9 \\
\hline Housing Authority & 35 & 16 & 1 & 4 & 36 & 15 \\
\hline Other & 4 & 2 & 0 & 0 & 4 & 2 \\
\hline No Response & 38 & 13 & 11 & 42 & 49 & 20 \\
\hline Total (Responses) 3 & 369 & & 30 & & 399 & \\
\hline
\end{tabular}


1) Who the client is; where he lives:

$\begin{array}{lcll}\text { Female } & 217 / 243^{* 1} & .89^{* 2} & .04^{* 3} \\ \text { Under 26 years } & 130 / 215 & .60 & .06 \\ \text { White } & 193 / 216 & .89 & .04 \\ \text { Unemployed } & 165 / 210 & .76 & .06 \\ \text { On Welfare } & 127 / 212 & .59 & .06 \\ \text { Income \$100-300/month } & 129 / 169 & .59 & .07 \\ \text { High Schoo1 or GED } & 141 / 205 & .65 & .06 \\ \text { Renting Apt. or House } & 164 / 175 & .76 & .06 \\ \text { Southeast Portland } & 94 / 205 & .43 & .07 * 4 \\ \text { Children--1-5 years } & 165 / 414 & .40 & * * * 6 * \\ \text { One or Two Children } & 114 / 195 & .53 & .07 \\ \text { Children with Her } & 167 / 181 & .77 & .06 \\ \text { Said Children not } & & & \\ \quad \text { Suffering } & 111 / 186 & .51 & .07 \\ \text { Children--Bad } & & & \\ \text { Behavior } & 27 / 60 & .36 & .12 \\ \text { Married Once } & 153 / 211 & .71 & .06 \\ \text { Married 1-5 years } & 130 / 213 & .60 & .06 \\ \text { Separated Now } & 195 / 215 & .90 & .04 \\ \text { Separated-1-6 months } & 104 / 192 & .51 & .07 \\ \text { Separated--1 or 2 times } & 110 / 154 & .55 & .08\end{array}$

2) Why or if the client wants a divorce:

$\begin{array}{lrrr}\text { Wants Divorce Only } & 170 / 199 & .78 & .06 \\ \text { Reasons for Divorce: } & 94 / 199 & .43 & .07 \\ \quad \text { Brutality } & 118 / 199 & .54 & .07 \\ \text { Spouse Drinks } & 84 / 199 & .39 & .07 \\ \quad \text { Arguments } & 74 / 199 & .34 & .06 \\ \quad \text { Lack of Affection } & & & \\ \text { Spouse Not Providing for } & 141 / 175 & .65 & .07 \\ \quad \text { Children } & 123 / 191 & .57 & .07 \\ \text { Wants Child Support } & 75 / 111 & .61 & .09 \\ \text { Will Demand Child Support } & & & \\ \text { Never Seen Marriage } & 147 / 203 & .68 & .06 \\ \quad \text { Counselor } & & & \end{array}$

3) Why the client came to Legal Aid and his contacts with other agencies:

Knew About Legal Aid from Welfare

$103 / 199$

Never Been to Legal Aid

$149 / 213$

.47

.69

.07

No Money For Private Attorney

$200 / 207$

.92

.03

Got to Legal Aid by Car, Bus, or Friend

$170 / 213$

.78

.06

Contact with Welfare

$131 / 179$

.60

.07

Contact with Food Stamps

$111 / 179$

.51

.07 
4) Whether the client has considered counseling to help with his problems:

Wanted Counseling

$33 / 199$

.15

Wanted Advice

20/199

.09

*1-.-Number of specific responses/Number of total responses. *2---Percentages.

*3---Confidence Levels.

*4-.-not possible to calculate a confidence level. 
EXHIBIT

- 


\section{This is a CONFIDENTIAL questionnaire which is being used by two Portland State students.}

Please feel free not to answer if you don't want to fill this out, or to leave any answers

blank; however, the information will be important to help Legal Aid to better assist its

clients. Some of these questions may be asked again by a Legal Aid staff member.

Please return this form to receptionist when finished. Thank You.

1.) Sex: Male_
2) Aemale
3) $\frac{\text { Race: }}{B] \text { (Check One) }}$

16) Are You Separated Now: (Check One)

If Yes: (Fill In)

Who Loft This Time: Self Months How Many Times Separated: _ times

\section{B] $\mathrm{ack}$}

White

Nexican

Indian

Oriental

4) Emnloyed: (Cheok Cne)

Nin

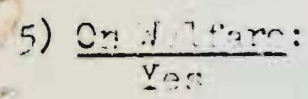

-

No

6) Income: (Take Home Amount)

Per Honth \$_ \$_

7) Education: (Check One or More) Grade School

High School

College

$\mathrm{CED}$

CEP t.reining

Voc. training

Bus. Schnol

Irede School

8) There I.ivine: (Check One)

Renting Ant.

Renting House

Owns Home

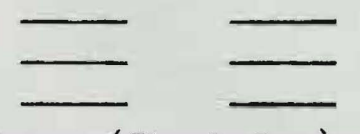

9) Who Iiving With Now: (Check One)

Alone
with Children
with Parents
with Relatives
With Friends

10) What Part of Town Do You Live In:

$\begin{array}{ll}\text { North } & \text { Southeast } \\ \text { Northeast__ } & \text { Southwest } \\ \text { Northwest__ } & \end{array}$

11) Ages of Children: (Fill. In Ages)

12) Where Are Children Living Now: (Check)

$\begin{array}{ll}\text { With You } & \text { Friends } \\ \text { With Soouse } & \text { Foster Home } \\ \text { Grandoarents } & \text { Adopted. }\end{array}$

other Relatives

13) Heve Children Suffered From This viarriage: Yes No

If Yes: How: (Check One or Miore)

Beaten Running Away

Poor Grades__ Skioring School

Left Alone_ Not in School

Use Drugs_ In Trouble

Bad Behavior

14) Hnw Lono Have You Been Married: (Fi]l In) Number of Years

15) Number of Times Married: (Fill. In Number) Self: Times

Snolise: — Times
17) What Have You Thought About to Heln With Your Family Problems: (Check One or Viore) $\begin{array}{ll}\text { Debt Counseling ___ Abortinn } \\ \text { Child Custody } & \text { Divorce }\end{array}$ Child Support__ Senaration Change of Name Advice Family Counseling_ Referral other__ Annulment

18) If You Are Consjdering a Divorce: Why: (Check One or More)

Caseworker Advised___ Brutality

Lack of Affection__ Spouse Drinks

Want to Remarry _ Arguments

Spouse Won't Work__ Spouse Gone Spouse Disabled_— Spnuse Has Boy

Spouse Unemployed__ Girl Friend Spouse Uses Drugs

19) Is Spouse Providing For Children Now: Yes_ No

If Yes: How: (Check One or More) Clothing__ Transportation. Food_- Entertainment Money_ Housine

20) Do You Want Child Supnort: (Check One) Yes No

If Yes: Will You Demand Sunnort:

If No: Is It Because He won't Pay Anyway:

21) Have You Ever Seen a Marriage Counse? or:

22) How Did. You Know About Leral Aid:

$\begin{array}{ll}\text { Welfare } & \text { Publicity } \\ \text { Friend } & \begin{array}{l}\text { Relatives } \\ \text { Phone Book }\end{array} \\ \text { Shouse } & \text { Private Attorney }\end{array}$

23) Have You Ever Been to Lega] Aid Before: Yes No

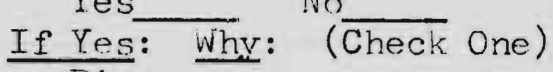

Divorce

other Leoal Problem

24) Did You Come to Legal Aid Because of Lack of Monev For a Private Attornev:

25) How Did Ynu Get to Legal Aid Today:

$\begin{array}{ll}\text { Own Car } & \text { Spouse Brought } \\ \text { Taxicab_ } & \text { Walked } \\ \text { Friend__ } & \text { Relative } \\ \text { Bus } & \end{array}$

26) Which Agencies Have You Seen in the Past. Year: (Check. One or liore)

\begin{tabular}{|c|c|}
\hline $\begin{array}{l}\text { Welfare } \\
\text { Juvenile } \\
\text { detention }\end{array}$ & $\begin{array}{l}\text { Probation } \\
\text { Parole } \\
\text { Food Stamps }\end{array}$ \\
\hline $\begin{array}{l}\text { Tuvenile Court } \\
\text { otrer Court. }\end{array}$ & $\begin{array}{l}\text { Nental Hoplth } \\
\text { Housino Allthority }\end{array}$ \\
\hline
\end{tabular}

